\title{
Article
}

\section{Co-exposure of C60 fullerene with benzo[a]pyrene results in enhanced biological effects in cells as determined by Fourier-transform infrared spectroscopy}

Li, Junyi, Hi, Li-Xin, Ying, Guang-Guo and Martin, Francis L Available at http://clok.uclan.ac.uk/17368/

Li, Junyi, Hi, Li-Xin, Ying, Guang-Guo and Martin, Francis L ORCID: 0000-00018562-4944 (2017) Co-exposure of C60 fullerene with benzo[a]pyrene results in enhanced biological effects in cells as determined by Fourier-transform infrared spectroscopy. Environmental Science: Nano . ISSN 2051-8153

It is advisable to refer to the publisher's version if you intend to cite from the work. http://dx.doi.org/10.1039/C7EN00164A

For more information about UCLan's research in this area go to http://www.uclan.ac.uk/researchgroups/ and search for < name of research Group>.

For information about Research generally at UCLan please go to http://www.uclan.ac.uk/research/

All outputs in CLoK are protected by Intellectual Property Rights law, including Copyright law. Copyright, IPR and Moral Rights for the works on this site are retained by the individual authors and/or other copyright owners. Terms and conditions for use of this material are defined in the policies page.

\section{CLoK}

Central Lancashire online Knowledge www.clok.uclan.ac.uk

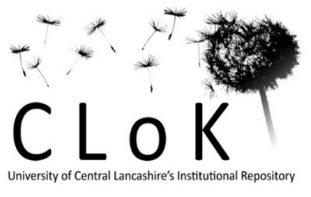




\section{Sano}

\section{Accepted Manuscript}

This article can be cited before page numbers have been issued, to do this please use: J. Li, L. Hi, G. Ying and F. L. Martin, Environ. Sci.: Nano, 2017, DOI: 10.1039/C7EN00164A.

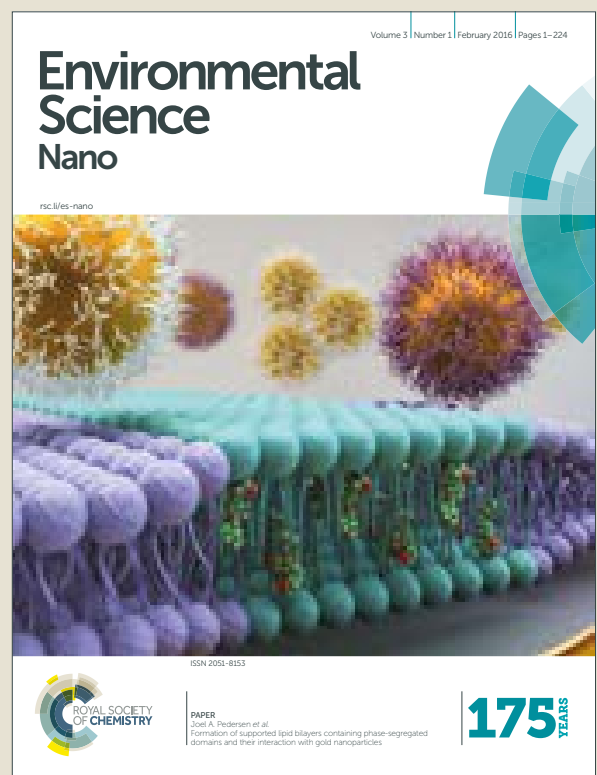

This is an Accepted Manuscript, which has been through the Royal Society of Chemistry peer review process and has been accepted for publication.

Accepted Manuscripts are published online shortly after acceptance, before technical editing, formatting and proof reading. Using this free service, authors can make their results available to the community, in citable form, before we publish the edited article. We will replace this Accepted Manuscript with the edited and formatted Advance Article as soon as it is available.

You can find more information about Accepted Manuscripts in the author guidelines.

Please note that technical editing may introduce minor changes to the text and/or graphics, which may alter content. The journal's standard Terms \& Conditions and the ethical guidelines, outlined in our author and reviewer resource centre, still apply. In no event shall the Royal Society of Chemistry be held responsible for any errors or omissions in this Accepted Manuscript or any consequences arising from the use of any information it contains. 


\section{Environmental Significance Statement}

There is an urgent need for approaches capable of lending insights into nanoparticle (NP)-induced effects in biological cells. Conventional assays such as those employing genotoxicity endpoints remain inconsistent. With increasing usage, carbon-based NPs are entering the environment and their effects either directly or in combination with other environmental contaminants remain to be understood. This study primarily exploits FTIR spectroscopy to derive signature fingerprints of cellular material based on chemical composition. Using computational algorithms to process spectral datasets, alterations post-exposure to $\mathrm{C}_{60}$ fullerene $\left(\mathrm{C}_{60}\right)$ with or without benzo[a]pyrene $(\mathrm{B}[a] \mathrm{P})$ were investigated. Exposure-induced spectral data points to gene expression and oxidative damage alterations; this is subsequently shown using more conventional assays. Low-dose $\mathrm{C}_{60}$ increased $\mathrm{B}[a] \mathrm{P}$-induced alterations, while alterations at high $\mathrm{C}_{60}$ concentrations appeared absent. This suggests that the interactions between NPs with toxic chemical contaminants are complex and remain to be fully understood. 


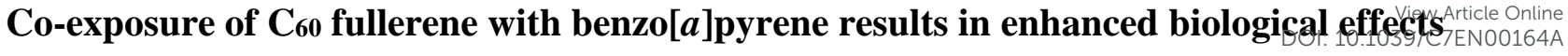
in cells as determined by Fourier-transform infrared spectroscopy

Junyi Li ${ }^{a}$, Li-Xin $\mathrm{Hu}^{b}$, Guang-Guo Ying ${ }^{b}$, Francis L. Martin ${ }^{c *}$

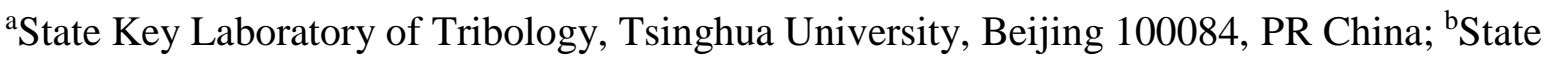
Key Laboratory of Organic Geochemistry, Guangzhou Institute of Geochemistry, Chinese Academy of Science, Guangzhou 510640, PR China; ${ }^{c}$ School of Pharmacy and Biomedical Sciences, University of Central Lancashire, Preston PR1 2HE, UK

*Corresponding author Email: flmartin@uclan.ac.uk; Tel.: +44 (0)1772 896482 
TOC graphic

Biospectroscopy signatures effects of binary mixture of $\mathrm{C}_{60}$ fullerene and benzo $[a]$ pyrene in cells

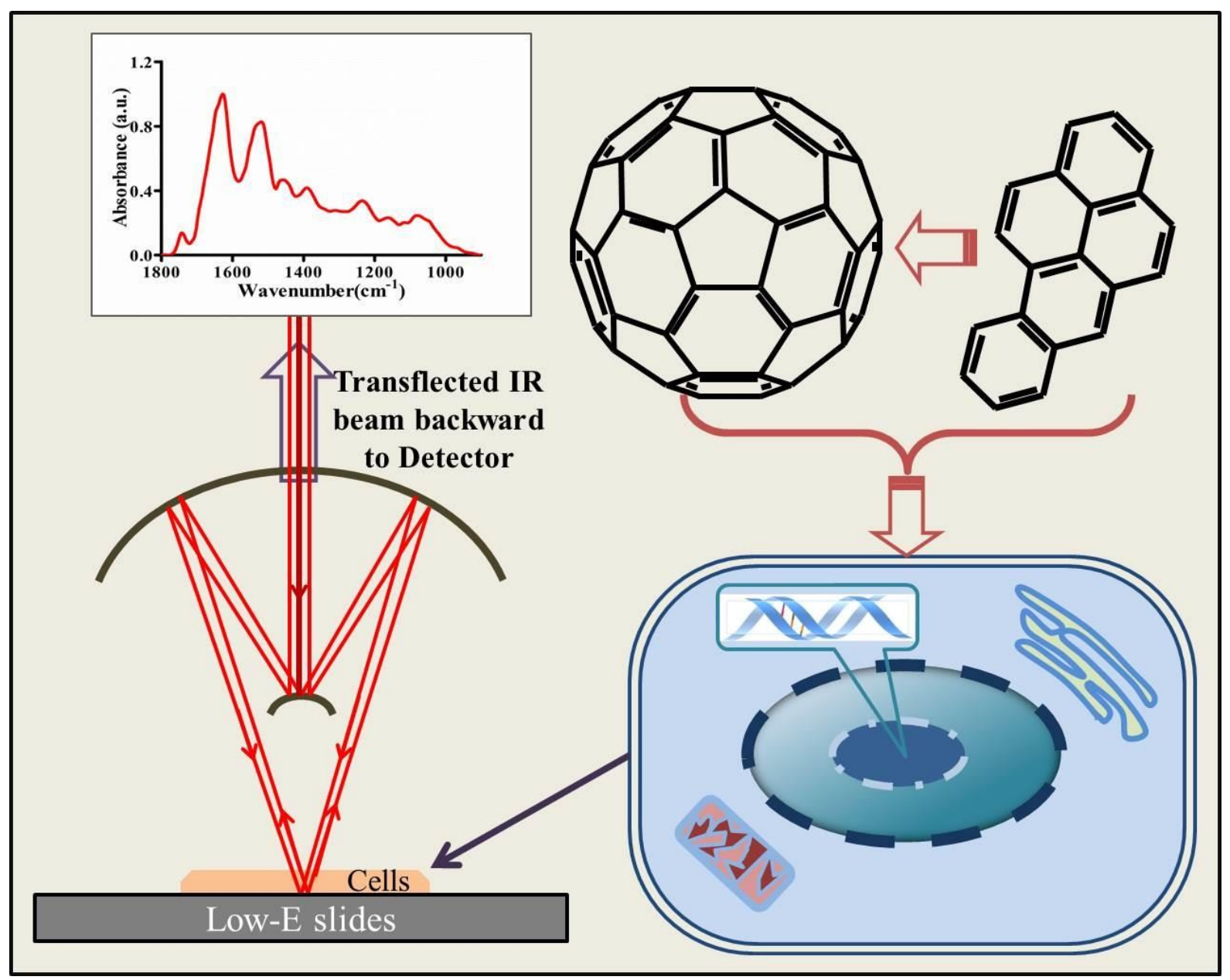




\begin{abstract}
$\mathrm{C}_{60}$ fullerene $\left(\mathrm{C}_{60}\right)$ is a promising manufactured carbon-based nanoparticles (NPs). With an increasing number of applications, it is being found in the environment. In addition, $\mathrm{C}_{60}$ is likely to associate with other environmental toxic contaminants. How such interactions with $\mathrm{C}_{60}$ can impact on the environmental fate, transport and bioavailability of toxicants remains unknown. Benzo $[a]$ pyrene $(\mathrm{B}[a] \mathrm{P})$ is a polycyclic aromatic hydrocarbon $(\mathrm{PAH})$. Herein, two cell lines (fish gill or MCF-7 cells) were employed to explore the biological impacts of coexposure to $\mathrm{C}_{60}$ and $\mathrm{B}[a] \mathrm{P}$. Post-exposure cells were interrogated using Fouriertransformation infrared (FTIR) microspectroscopy. By inputting spectral data into principal component analysis and linear discriminant analysis, data reduction allowed for visualisation of cell categorization and identification of wavenumber-related biomarkers corresponding to cellular alterations. Our results indicate that low-dose $\mathrm{C}_{60}$ increases $\mathrm{B}[a] \mathrm{P}$-induced alterations, while $\mathrm{C}_{60}$ at high concentrations reduces these effects. We also found that although $\mathrm{C}_{60}$ coexposure increases $\mathrm{B}[a] \mathrm{P}$-induced $C Y P 1 A 1$ induction, co-exposure seemingly attenuates the levels of oxidative damage induced by either agent singly. This suggests that interactions between environmental NPs and contaminants are complex and unpredictable.
\end{abstract}




\section{Introduction}

With the rise of nanotechnology, there has been a rapid increase in the commercial use of nanoparticles (NPs). However, little is known regarding the fate and behaviour of engineered NPs in the environment, and concerns have emerged regarding their potential impact on human health. ${ }^{1,2}$ Furthermore, quantitative analytical methods are required to determine environmental concentrations and, enable both effect and exposure assessments. Many methods still need optimization and development, especially for new types of NPs. ${ }^{3-6}$ There is an urgent need for analytical methods to adequately assess the risk of NPs.

$\mathrm{C}_{60}$ fullerene $\left(\mathrm{C}_{60}\right)$, the first manufactured NP, possesses unique physical and chemical properties, which makes it a candidate agent for many nanotechnological applications in industrial and medical fields. ${ }^{7-10}$ However, its extremely small size, unique conformation, large surface area, and propensity for surface modification raise the possibility that $\mathrm{C}_{60}$ could pose a hazard to humans and other living organisms. ${ }^{11}$ It seems that the cytotoxicity of $\mathrm{C}_{60}$ differs depending on the type of cells exposed and how test suspensions are prepared. ${ }^{12,13}$

Included in the debate regarding NP-induced acute toxicity, there are emerging concerns about their release into the environment in that NPs may not only just interfere with biological systems, but also may interact with other contaminants such as polycyclic aromatic hydrocarbons (PAHs). Consequently, NPs could affect the fate, transportation and bioavailability of pollutants in binary mixtures. In aquatic environments, contaminants can accumulate in aqueous NPs and this accumulation appears to affect the physicochemical property of both NP and the co-contaminant. ${ }^{14}$ Investigations show that NPs seem to be highly reactive in their interactions with other contaminants. Furthermore, it has been noted that nano-silica could facilitate the cellular uptake of metals, and induce higher levels of 
damage than that induced by metal or nano-silica alone. ${ }^{15}$ This type of delivery mechanisuiguesticle Online the so called 'Trojan horse' effect. In another example, it was found that nano- $\mathrm{TiO}_{2}$ enhanced the bioaccumulation and toxicity of copper in Daphnia magna. ${ }^{16}$ However, studies investigating the effects of co-contamination with carbon-based NPs seem to be less conclusive, although carbon nanomaterials appear to be highly interacting with chemicals in the environment. ${ }^{17-19}$ Single-walled carbon nanotubes were found to act as a contaminant carrier and enhance the accumulation of phenanthrene in the digestive track of fish. ${ }^{20}$ Another study suggests that co-exposure with carboxyl-functionalized single-walled carbon nanotubes significantly inhibits the bioactivity of adsorbed $17 \alpha$-ethinylestradiol $\left(\mathrm{EE}_{2}\right)$ in cultured cells. ${ }^{21}$

Polycyclic aromatic hydrocarbons (PAHs) are a class of widespread organic compounds with two or more fused aromatic rings; they have a relatively low solubility in water, but are highly lipophilic. ${ }^{22}$ Benzo $[a]$ pyrene $(\mathrm{B}[a] \mathrm{P})$ is a $\mathrm{PAH}$ that is pro-carcinogenic. It is a potent ligand for the cytosolic aryl hydrocarbon receptor (AhR), which may mediate teratogenic and carcinogenic effects of certain environmental pollutants. ${ }^{23}$ In cells, $\mathrm{B}[a] \mathrm{P}$ can bind to AhR and activate it, or it is effectively metabolised by several xenobiotic metabolizing enzymes to $\mathrm{B}[a] \mathrm{P}-7,8$-diol-9,10-epoxide (BPDE), which is the ultimate carcinogenic form, and generates bulky chemical-DNA adducts. ${ }^{24-26}$

It is highly possible that carbon-based nanomaterials would interact with PAHs and be a co-contaminating influence in the environment. In order to understand how this kind of coexposure will impact on toxicity, cells were co-exposed to $\mathrm{C}_{60}$ with $\mathrm{B}[a] \mathrm{P}$. Effects in cells were then assessed using Fourier-transform infrared (FTIR) microspectroscopy. Such biospectroscopy provides a rapid, reagent-free and non-destructive method for biological analysis. ${ }^{27}$ Therefore, IR spectroscopy has been widely applied in biological research, for disease diagnosis ${ }^{28}$, stem cell characterisation ${ }^{29}$ and toxicity assessment ${ }^{30}$. The mid-IR region 
In this study, two cell lines, including a fish gill cell line and a mammalian cell line were used to examine the in vitro biological effects following co-exposure to $\mathrm{C}_{60}$ and $\mathrm{B}[a] \mathrm{P}$; the cellular response was determined using FTIR spectroscopy. In line with previous investigations, three relatively low doses were employed $(\mathrm{B}[a] \mathrm{P}$ exposure concentrations at $10^{-6} \mathrm{M}, 10^{-7} \mathrm{M}$ and $10^{-8} \mathrm{M} ; \mathrm{C}_{60}$ at $0.1 \mathrm{mg} / \mathrm{L}, 0.01 \mathrm{mg} / \mathrm{L}$ and $\left.0.001 \mathrm{mg} / \mathrm{L}\right) .{ }^{32,33}$ Spectral alterations were associated with effects on AhR-inducible CYP1A1, DNA damage inferred by $P 21^{W A F 1 / C I P 1}$ and oxidative stress [measured by thiobarbituric acid reactive substances (TBARS) and levels of intracellular reactive oxygen species (ROS)]. This study aimed to gain insights into a binary exposure including a carbon-based NP and chemical contaminant.

\section{Materials and Methods}

\section{Chemicals and carbon nanoparticles (NPs)}

All test agents were purchased from Sigma. B $[a] \mathrm{P}$ was HPLC-grade $(>96 \%)$ in powder-form, while dimethyl sulfoxide (DMSO) used as solvent was GC-grade ( $\geq 99.5 \%)$. Bovine serum albumin (BSA), also obtained from Sigma, was $\geq 98 \%$ pure. $\mathrm{C}_{60}$ (from Sigma) had a purity $>99.5 \%$ and particle size of $1 \mathrm{~nm}$. It was analysed by Raman spectroscopy (Renishaw PLC, Gloucestershire, UK) with a $785 \mathrm{~nm}$ laser, and determined to be of high 


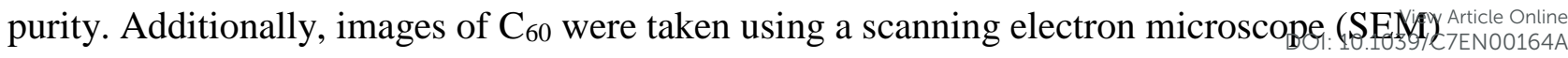
[JSM 5600 (JEOL)] [see Electronic Supporting Information (ESI) Figure S1].

$\mathrm{B}[a] \mathrm{P}$ was dissolved in DMSO, and stock solutions were made at concentrations of $10^{-3} \mathrm{M}, 10^{-4} \mathrm{M}$ and $10^{-5} \mathrm{M} . \mathrm{C}_{60}$ were dispersed in $1 \%$ BSA solution following a $15-\mathrm{min}$ ultrasonication in an ice-water bath and stock solutions were made at concentrations of 100 $\mathrm{mg} / \mathrm{L}, 10 \mathrm{mg} / \mathrm{L}$ and $1 \mathrm{mg} / \mathrm{L}$. Agglomeration could be observed in the solution due to its lipophilic properties. To ensure a homogeneous mixture of chemical agents, solvent or exposure medium, and to avoid any solvent-specific effects, stock solutions and exposure medium were mixed prior to application to the cells. Accordingly, as NPs and $\mathrm{B}[a] \mathrm{P}$ were dispersed in $1 \%$ BSA solution and DMSO respectively, each experimental medium contained a final level of $0.1 \%$ (vol/vol) $1 \%$ BSA solution and DMSO. An experimental medium containing $0.1 \%$ (vol/vol) $1 \%$ BSA solution and DMSO without test agent was used as vehicle control. All experimental media were prepared $72 \mathrm{~h}$ prior to cell exposure and stored at $4^{\circ} \mathrm{C}$, which allowed absorption equilibration of $\mathrm{B}[a] \mathrm{P}$ onto $\mathrm{C}_{60}$. Mixture treatment compositions were as follows: Mix $1,10^{-6} \mathrm{M} \mathrm{B}[a] \mathrm{P}+0.001 \mathrm{mg} / \mathrm{L} \mathrm{C} 60 ; \mathrm{Mix} 2,10^{-6} \mathrm{M} \mathrm{B}[a] \mathrm{P}+$ $0.01 \mathrm{mg} / \mathrm{L} \mathrm{C} 60 ;$ Mix $3,10^{-6} \mathrm{M} \mathrm{B}[a] \mathrm{P}+0.1 \mathrm{mg} / \mathrm{L} \mathrm{C} 60 ;$ Mix 4, $10^{-7} \mathrm{M} \mathrm{B}[a] \mathrm{P}+0.1 \mathrm{mg} / \mathrm{L} \mathrm{C} 60 ;$ and, $\operatorname{Mix} 5,10^{-8} \mathrm{M} \mathrm{B}[a] \mathrm{P}+0.1 \mathrm{mg} / \mathrm{L} \mathrm{C} 60$.

\section{Cell culture}

Human breast cancer MCF-7 cells were cultured in Dulbecco's modified essential medium (DMEM) supplemented with 10\% heat-inactivated foetal bovine serum, penicillin (100 U/mL), and streptomycin $(100 \mu \mathrm{g} / \mathrm{mL}) . \mathrm{MCF}-7$ cells were maintained in a humidified atmosphere with $5 \% \mathrm{CO}_{2}$ in air at $37^{\circ} \mathrm{C}$. Gill cells for primary cultures were derived from gills of rainbow trout (Oncorhynchus mykiss) ${ }^{34}$. The cells were cultured with Leibovitz's L15 culture media supplemented with $10 \%$ heat-inactivated foetal bovine serum, penicillin 


\section{Exposure protocol}

For MCF-7 cells, the same medium was used for incubation before and during exposure (namely exposure medium), while L15 medium was only used for gill cells prior to exposure, but a different medium, L15/ex, was then introduced as the experimental medium during exposures. L-15/ex medium was initially validated in the RTgill-w1 cell line. L15/ex medium contains only salts, galactose and pyruvate to provide an isotonic environment, and a source of energy; as such, it is fully defined ${ }^{35,36}$. Bioavailability of test chemicals in this in vitro system is not influenced by a serum component. Binding of hydrophobic test chemicals to constituents of serum was suggested to contribute to the systematic deviation of mammalian cell viability versus fish acute toxicity depending on the chemicals' octanolwater partition coefficient (Kow) and is also a likely cause of under-estimation of fish acute toxicity using fish cell lines ${ }^{36}$.

For exposure, cells were directly grown on Low-E slides (Kevley Technologies, OH, USA) in 45-mm culture dishes. Prior to cell seeding, Low-E slides were immersed in ethanol for $30 \mathrm{~min}$. Following rinsing in sterile water, Low-E slides were then stored in empty culture dishes and dried in an incubator. Confluent cells in $75 \mathrm{~cm}^{2}$ flasks were disaggregated with trypsin $(0.05 \%)$ /EDTA $(0.02 \%)$ solution, and were immediately re-suspended in complete medium. Cells were then seeded to the culture dishes and allowed to attach on the slides and to form a cell layer on the Low-E slides. After $72 \mathrm{~h}$, the original medium was removed and experimental medium containing test agents (or not) was added. After 24-h incubation, the 


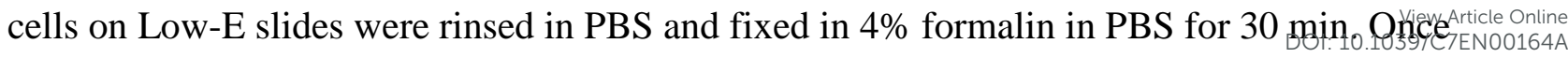
fixed, the slides were rinsed in PBS and given a quick wash $(\sim 3 \mathrm{sec})$ in distilled water. Following air-drying overnight, slides were stored in a desiccator until analysis.

\section{Spectrochemical analysis}

All cell samples on Low-E slides were interrogated using a Bruker TENSOR 70 FTIR spectrometer (Bruker Optics Ltd., Germany) equipped with a HYPERION 1000 microscope containing a liquid nitrogen-cooled detector. Instrument parameters were set at 32 scans and $8 \mathrm{~cm}^{-1}$ resolution. For each slide, some 20 IR spectra were acquired at different points across the sample. Prior to starting a new slide or after each ten spectra, a background was taken.

Spectral data acquired from FTIR spectroscopy were processed using IRootLab toolbox (http://trevisanj.github.io/irootlab/) running on MATLAB r2010a (The MathWorks, Inc., US). IR spectra were pre-processed as follows: cut to $1800-900 \mathrm{~cm}^{-1}$ (the biochemical fingerprint range), rubberband baseline corrected, and normalisation to Amide I peak. Computational analysis using multivariate techniques included principal component analysis (PCA) and linear discriminant analysis (LDA), which can efficiently analyse large spectral datasets. Following pre-processing, PCA was applied to the spectral dataset. PCA is an unsupervised technique employed to reduce the dimensions of the data. Undoubtedly, PCA is capable of identifying some important biochemical information in the spectral data. However, it has less discriminating power due to the fact that it is an unsupervised procedure. In order to interpret such complex biochemical information, further data analysis by using supervised procedures such as LDA is often applied. Thus, the output derived from PCA was inputted into LDA ${ }^{37}$. The first ten PC factors from PCA were used for LDA since that accounted for $>99 \%$ variance $^{31}$. Multivariate analysis results were visualized either as scores plots and/or cluster vectors plot. In scores plots, nearness between two groups implies similarity, 


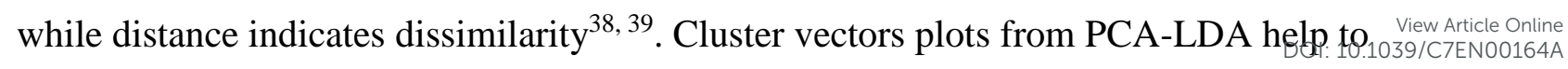
reveal the biochemical alterations associated with each category in the dataset. To simplify the identification of the main biochemical alterations of each group, cluster vectors peak plots were used to indicate the top seven peaks in the cluster vectors plots.

\section{Quantitative real-time reverse transcriptase (RT)-PCR}

Routinely-cultured MCF-7 cells were disaggregated and re-suspended in complete medium (DMEM, $10 \%$ FCS) prior to seeding aliquots $\left(5 \mathrm{ml}, \approx 1 \times 10^{5}\right.$ cells) into 60 -mm petri dishes $^{40}$. Following 24-h incubation, cells were treated (using exposure medium as described above) for a further $24 \mathrm{~h}$ with $10^{-8} \mathrm{M} \mathrm{B}[a] \mathrm{P}, 0.1 \mathrm{mg} / \mathrm{L} \mathrm{C} 60$ fullerene or a combination of both; a vehicle control was also included. Cells were then washed twice with PBS prior to lysis and total RNA extraction using the Qiagen RNeasy® Kit in combination with the Qiagen RNasefree DNase kit (QIAGEN Ltd, Crawley, UK). DNase was incorporated into the extraction procedure in order to remove residual DNA, e.g., pseudogene. RNA quality was routinely assessed in a $1.2 \%$ formaldehyde agarose gel; yield and purity were checked using a spectrophotometer. RNA $(0.4 \mu \mathrm{g})$ was reverse transcribed in a final volume of $20 \mu \mathrm{l}$ containing Taqman ${ }^{\circledR}$ reverse transcription reagents (Applied Biosystems, Warrington, UK): $1 \times$ Taqman reverse transcriptase $(\mathrm{RT})$ buffer; $\mathrm{MgCl}_{2}(5.5 \mathrm{mM})$; oligo d(T) ${ }_{16}(2.5 \mu \mathrm{M}) ; \mathrm{dNTP}$ mix (dGTP, dCTP, dATP and dTTP; each at a concentration of $500 \mu \mathrm{M})$; RNase inhibitor $(0.4 \mathrm{U} / \mu \mathrm{l})$; RT (MultiScribe $\left.{ }^{\mathrm{TM}}\right)(1.25 \mathrm{U} / \mu \mathrm{l})$ and RNase-free water. Reaction mixtures were then incubated at $25^{\circ} \mathrm{C}(10 \mathrm{~min}), 48^{\circ} \mathrm{C}(30 \mathrm{~min})$ and $95^{\circ} \mathrm{C}(5 \mathrm{~min})$.

cDNA samples were stored at $-20^{\circ} \mathrm{C}$ prior to use. Primers (Table 1) for cyclindependent kinase inhibitor 1A [CDKN1A (P21 $1^{\text {WAFl/CIP1 }}$, GenBank accession no. NM_078467)] and CYP1Al (GenBank accession no. BC023019) and endogenous control $\beta$-ACTIN (GenBank accession no. AK222925) were chosen using Primer Express software 2.0 (Applied Biosystems) and designed so that one primer spanned an exon boundary. Specificity 
was confirmed using the NCBI BLAST search tool. Quantitative real-time PCR was View Article Online performed using an ABI Prism 7000 Sequence Detection System (Applied Biosystems). Reaction mixtures contained $1 \times$ SYBR ${ }^{\circledR}$ Green PCR master mix (Applied Biosystems); forward and reverse primers (Invitrogen Life Technologies) at a concentration of $300 \mathrm{nM}$ $\left(P 21^{W A F 1 / C I P 1}, C Y P 1 A 1\right.$ or $\beta$-ACTIN); for $P 21^{W A F 1 / C I P 1}$ or $C Y P 1 A 1$ amplification $20 \mathrm{ng}$ cDNA template or for $\beta$-ACTIN amplification $5 \mathrm{ng}$ cDNA template; made to a total volume of $25 \mu 1$ with sterile $\mathrm{H}_{2} \mathrm{O}$. Thermal cycling parameters included activation at $95^{\circ} \mathrm{C}(10 \mathrm{~min})$ followed by 40 cycles each of denaturation at $95^{\circ} \mathrm{C}(15 \mathrm{sec})$ and annealing/extending at $60^{\circ} \mathrm{C}(1 \mathrm{~min})$. Each reaction was performed in triplicate and 'no-template' controls were included in each experiment. Dissociation curves were run to eliminate non-specific amplification, including primer dimers. In control cell populations, averaged threshold cycle values of amplified cDNA were in the 25-30 range for CYP1Al.

\section{The thiobarbituric acid (TBA) assay for lipid peroxidation}

Lipid peroxidation was measured as a function of TBA reactive substances (TBARS), including malondialdehyde-TBA adduct production ${ }^{41,42}$. Routinely cultured MCF-7 cells were disaggregated and re-suspended in complete medium (DMEM, 10\% FCS) prior to seeding aliquots $\left(10 \mathrm{ml}, \approx 1 \times 10^{6}\right.$ cells $)$ into $75 \mathrm{~cm}^{2}$ flasks. Following 24 -h incubation, cells were treated (using exposure medium as described above) for a further $24 \mathrm{~h}$ with $10^{-8} \mathrm{M}$ $\mathrm{B}[a] \mathrm{P}, 0.1 \mathrm{mg} / \mathrm{L} \mathrm{C}_{60}$ fullerene or a combination of both; a vehicle control was also included. Cells were harvested by scraping, washing with PBS and re-suspension in deionized water containing $8.1 \%$ SDS, $20 \%$ acetic acid and $0.8 \%$ thiobarbituric acid. Resultant mixtures were incubated in a boiling water bath for $1 \mathrm{~h}$. After cooling, $n$-butanol:pyridine mixture (15:1, $\mathrm{v} / \mathrm{v}$ ) was added and the reaction mixtures were centrifuged at $1600 \mathrm{~g}$ for $15 \mathrm{~min}$. In decanted supernatants, malondialdehyde was assayed at $532 \mathrm{~nm}$. TBARS concentrations were 
expressed as nmol/mg protein, as determined using the Bradford method, using 1,133:35-1039/C7ENO0164A tetraethoxypropane as a reference standard. Results are presented as the Mean \pm SD of five independent experiments, each performed in duplicate.

\section{Determination of intracellular reactive oxygen species (ROS) levels}

The fluorescent probe to oxidative damage, 2'7'-dichlorofluorescein diacetate (DCFH-DA), in combination with flow cytometry was employed. Routinely cultured MCF-7 cells were disaggregated and re-suspended in complete medium (DMEM, 10\% FCS) prior to seeding aliquots $\left(10 \mathrm{ml}, \approx 1 \times 10^{6}\right.$ cells $)$ into $75 \mathrm{~cm}^{2}$ flasks. Following 24 -h incubation, cells were treated (using exposure medium as described above) for a further $24 \mathrm{~h}$ with $10^{-8} \mathrm{M} \mathrm{B}[a] \mathrm{P}, 0.1$ $\mathrm{mg} / \mathrm{L} \mathrm{C}_{60}$ fullerene or a combination of both; a vehicle control was also included. Thirty min prior to the end of the above incubation period, DCFH-DA was added to each incubation mix; the underlying principle is that upon diffusion across the lipid cell membrane, deacetylation by intracellular esterases generates 2'7'-dichlorodihydrofluorescein $\left(\mathrm{DCFH}_{2}\right)$. With intracellular ROS generation, $\mathrm{DCFH}_{2}$ is oxidized to 2' $7^{\prime}$-dichlorofluorescein (DCF), a highly fluorescent end-product. At the end of the incubation period, cells were disagreggated with warm trypsin/EDTA and washed with PBS, upon which intracellular ROS levels were determined using a FACScan flow cytometer (Becton Dickinson) at $488 \mathrm{~nm}$ (excitation) and $525 \mathrm{~nm}$ (emission). For each treatment, a minimum of 10,000 events were collected and analysed by CellQuest software. Results are presented as the Mean \pm SD of five independent experiments, each performed in duplicate.

\section{Results and discussion}

Post-exposure to the test agents studied herein, cells were harvested and interrogated by FTIR spectroscopy. This analysis gave rise to a large spectral dataset containing 12 


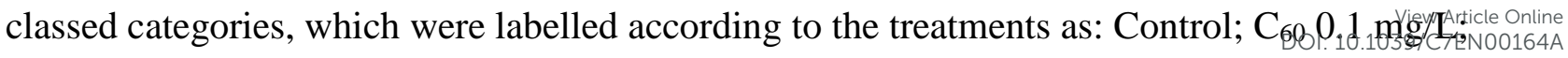
$\mathrm{C}_{60} 0.01 \mathrm{mg} / \mathrm{L} ; \mathrm{C}_{60} 0.001 \mathrm{mg} / \mathrm{L} ; \mathrm{B}[a] \mathrm{P}$ at $10^{-8} \mathrm{M} ; \mathrm{B}[a] \mathrm{P}$ at $10^{-7} \mathrm{M} ; \mathrm{B}[a] \mathrm{P}$ at $10^{-6} \mathrm{M} ; \mathrm{Mix} 1$ $\left(\mathrm{C}_{60} 0.001 \mathrm{mg} / \mathrm{L} \& \mathrm{~B}[a] \mathrm{P}\right.$ at $\left.10^{-6} \mathrm{M}\right) ; \mathrm{Mix} 2\left(\mathrm{C}_{60} 0.01 \mathrm{mg} / \mathrm{L} \& \mathrm{~B}[a] \mathrm{P}\right.$ at $\left.10^{-6} \mathrm{M}\right) ; \mathrm{Mix} 3\left(\mathrm{C}_{60}\right.$ $0.1 \mathrm{mg} / \mathrm{L} \& \mathrm{~B}[a] \mathrm{P}$ at $\left.10^{-6} \mathrm{M}\right) ; \operatorname{Mix} 4\left(\mathrm{C}_{60} 0.1 \mathrm{mg} / \mathrm{L} \& \mathrm{~B}[a] \mathrm{P}\right.$ at $\left.10^{-7} \mathrm{M}\right) ;$ and, Mix $5\left(\mathrm{C}_{60} 0.1\right.$ $\mathrm{mg} / \mathrm{L} \& \mathrm{~B}[a] \mathrm{P}$ at $\left.10^{-8} \mathrm{M}\right)$. Parallel sets of experiments were conducted in the MCF-7 cell and RTgill-w1 cell lines. Further analyses for CYP1A1 induction, lipid peroxidation and generation of intracellular ROS were conducted at selected concentrations in MCF-7 cells.

As specific wavenumbers in IR spectra may be used as markers of chemical entities in cells, their intensity absorbance following simple pre-processing (including baseline correction and normalization) may be used to assess treatment-induced alterations in target cells. The intensity absorbance at $1400 \mathrm{~cm}^{-1}$ is used as a protein marker as it corresponds to $\mathrm{C}=\mathrm{O}$ symmetric stretching of amino acids and $1740 \mathrm{~cm}^{-1}$ is associated with $\mathrm{C}=\mathrm{O}$ stretching vibrations of lipids. Thus, the protein-to-lipid ratio using the intensity absorbance at these two vibration modes may assess cell proliferation post-exposure ${ }^{38}$. Similarly, other absorbance ratios are employed including: intensity absorbance ratio of $1650 \mathrm{~cm}^{-1}$ to $1084 \mathrm{~cm}^{-1}$ as ratio of protein/nucleic acid $\left(1650 \mathrm{~cm}^{-1}\right.$ corresponding to Amide I in protein; $1084 \mathrm{~cm}^{-1}$ corresponding to $v_{s} \mathrm{PO}_{2}^{-}$for DNA/RNA $)^{43}$, and intensity ratio of $\left(996 \mathrm{~cm}^{-1}\right) /\left(966 \mathrm{~cm}^{-1}\right)$ used as RNA/DNA ratio ${ }^{43,44}$.

A tendency for an elevated protein-to-lipid ratio indicates that the test agents used give rise to active cell proliferation ${ }^{45}$. Our findings suggested that most of the treatments in gill cells significantly activated cell proliferation compared with the control, while in MCF-7 cells, only exposure of Mix 4 induced significant proliferation (Figure 1a; see ESI Table S1). In contrast to the protein-to-lipid ratio, the protein-to-nucleic acid ratio exhibited a downregulation following most exposures in gill cells except for the Mix 3 (Figure 1b; see 
As mid-IR spectra from multi-constituent biological samples are rich in biochemical information and complex, using simple intensity absorbance ratios (peak-to-peak ratio) is inadequate for interpretation of biological alterations ${ }^{46}$. Thus, multivariate data-analysis techniques were employed to help with bioinformatics extraction in spectral datasets ${ }^{47,48}$. Combinations of different categories with emphasis on different scenarios to explore the postexposure-effects from single agent or binary treatments were examined. When such spectral datasets are processed by computational analysis, alterations induced by single agents or binary mixtures can be determined. Based on PCA-LDA, dimensional (1-, 2- or 3-D) scores plots are generated for visualisation using the first three LD factors, where most segregation among categories is observed. The first two factors are particularly displayed in 1-D scores plots with their corresponding loadings plots, which identify the wavenumbers responsible for segregation. Additionally, cluster vectors plots are applied to the dataset of binary mixture 
exposure, so that the global alterations in cells induced by each treatment could be identififivgarticle Online compared with the control group.

When the spectral datasets containing whole categories were inputted into PCA-LDA (Dataset Total), 3-D scores plots were generated for visualisation. However, it is difficult to identify segregation in 3-D or 2-D scores plots, with so many categories (see ESI Figure S2). Thus, displaying the first two LD scores in 1-D plots gives rise to a clearer interpretation of segregation among categories (Figure 2; see ESI Figure S3). For both LD1 and LD2 space, the corresponding loadings plots are displayed with the top seven wavenumbers marked. In LD1 space, the wavenumbers derived from the spectral dataset of gill cells ranks as: $1232 \mathrm{~cm}^{-}$ ${ }^{1}$ (DNA/RNA; vas $\mathrm{PO}_{2}^{-}$), $1709 \mathrm{~cm}^{-1}$ (lipid), $1664 \mathrm{~cm}^{-1}$ (Amide I), $1070 \mathrm{~cm}^{-1}$ (DNA/RNA; $v_{s} \mathrm{PO}_{2}^{-}$), $985 \mathrm{~cm}^{-1}$ (protein phosphorylation), $1417 \mathrm{~cm}^{-1}$ (amino acid; $v\left[\mathrm{COO}^{-}\right]$), and $1556 \mathrm{~cm}^{-1}$ (Amide II). Those derived from MCF-7 cells in LD1 space were similar to gill cells: 1101 $\mathrm{cm}^{-1}$ (DNA/RNA, $v_{s} \mathrm{PO}_{2}^{-}$), $1508 \mathrm{~cm}^{-1}$ (Amide II), $1026 \mathrm{~cm}^{-1}$ (glycogen), $1566 \mathrm{~cm}^{-1}$ (Amide II), $983 \mathrm{~cm}^{-1}$ (protein phosphorylation), $1406 \mathrm{~cm}^{-1}$ (amino acid; $v\left[\mathrm{COO}^{-}\right]$), and $1712 \mathrm{~cm}^{-1}$ (lipid). The loadings plots indicate how each variance (i.e., wavenumber) contributes to the discrimination between the categories in the dataset. These wavenumbers correspond to specific chemical entities, which might be used as biomarkers in risk assessment, in which relative importance is identified in loadings plots. However, in LD2 space the loadings plots for each cell line placed emphasis on different biomarkers; most pronounced wavenumbers in loadings plots from gill cells were in the DNA/RNA region $\left(\sim 1250-1000 \mathrm{~cm}^{-1}\right)$, while in MCF-7 cells they mostly appeared to be in the lipid / protein (Amide I) region ( 1750-1500 $\mathrm{cm}^{-1}$ ). For both cell lines, significant alterations in LD1 and LD2 space were observed between the exposed groups and the control in both LD1 and LD2 space, except following treatment with Mix 3 (see ESI Table S4). For gill cells, its corresponding Dataset Total indicated that in both LD1 and LD2 space, binary treatment with both high-dose of $\mathrm{B}[a] \mathrm{P}$ and 
$\mathrm{C}_{60}$ is likely to result in highly reduced effects in gill cells, while exposure to a high-dosevise Article Online the one agent mixed with a low-dose of the other agent could greatly enhance toxicity in gill cells. However, when MCF-7 cells were exposed to the test agents, the response modes in the two LD spaces were presented in different ways. In LD1 space, MCF-7 cells following single-agent exposure exhibit a linear response (high response with high-dose), while in LD2 space low-dose effects were represented with $\mathrm{B}[a] \mathrm{P}$ treatment. As MCF-7 cells exposed to binary agents, alterations were observed but without obvious enhancement, except that of Mix 1 in LD1. This fits with the effects on lipid peroxidation and intracellular ROS; singly both $\mathrm{B}[a] \mathrm{P}$ and $\mathrm{C}_{60}$ elevated these markers of oxidative stress, but in combination there is an apparent attenuation of this effect (Table 3). Through CYPlAl induction, $\mathrm{B}[a] \mathrm{P}$ might be expected to increase intracellular ROS generation. $\mathrm{C}_{60}$ is known to generate lipid peroxidation mediated via ROS leading to its cytotoxicity ${ }^{49}$, but is also known to be a ROS scavenger through its ability to bind up to six electrons ${ }^{42}$.

The dataset of the control category compared to those from single treatment with either $\mathrm{C}_{60}$ or $\mathrm{B}[a] \mathrm{P}$ was explored to examine for single-agent effects (Dataset $\mathrm{C}_{60}$ or Dataset $\mathrm{B}[a] \mathrm{P})$. When cells were exposed to $\mathrm{C}_{60}$, both gill cells and MCF-7 cells were likely to show a linear dose-response in the LD1 space (Figure 3). Gill cells were significantly affected by $\mathrm{C}_{60}$ at each dose in both LD spaces, while with MCF-7 cells only treatment of $0.1 \mathrm{mg} / \mathrm{L}$ in LD1 space and treatment of $0.01 \mathrm{mg} / \mathrm{L}$ in $\mathrm{LD} 2$ space appeared to be significant (see ESI Table S4). In the LD1 loadings plot derived from gill cells, the most pronounced wavenumbers were related to Amide I, glycogen, DNA/RNA, and lipid regions (Figure 3a, ESI Table S6). This is similar for MCF-7 cells in that segregation in LD1, mostly resulted from alterations in Amide I, lipid, Amide II and DNA/RNA (Figure 3c, see ESI Table S8). These spectral profiles indicate that $\mathrm{C}_{60}$ is capable of not only inducing alterations in outer cellular structures (lipids and proteins), but also in internal components of DNA/RNA, 
namely genotoxicity ${ }^{50,51}$. It is suggested that the genotoxicity of $\mathrm{C}_{60}$ is possibly caused by by $y_{90} \mathrm{C}_{\mathrm{C}}$ Article Online ROS pathway $^{52}$. Further work will be needed to delineate the time course of ROS generation and consequent cytotoxicity; it would be important to guard against missing transient effects.

However, $\mathrm{B}[a] \mathrm{P}$ treatment was likely to result in a non-linear dose-response in both cell lines, and in both LD spaces significant segregation was observed in the treated categories compared with the control category, except that of gill cells exposed to $\mathrm{B}[a] \mathrm{P}$ at $10^{-8} \mathrm{M}$ (Figure $3 \mathrm{~b} \& 3 \mathrm{~d}$, ESI Table S4). B $[a] \mathrm{P}$ specifically induces alterations in DNA/RNA, as loadings plots in both LD1 and LD2 show obviously pronounced peaks in corresponding wavenumbers (Figure 3, see ESI Figure S4 and Table S6). This indicates that $\mathrm{B}[a] \mathrm{P}$ is a genotoxic compound inducing DNA damage ${ }^{25,53}$, which is consistent with previous studies from our group ${ }^{32}$. Moreover, a low-dose effect is observed in cells following $\mathrm{B}[a] \mathrm{P}$ exposure.

To gain insights into the mechanism underlying the action of binary exposure in cells, specific categories were combined as an associated dataset (Dataset Mix). In these datasets, cluster vectors plots were employed to indicate the most pronounced wavenumbers corresponding to alterations in each treatment category compared to control. When spectral data from $0.1 \mathrm{mg} / \mathrm{L} \mathrm{C} \mathrm{C}_{60}, 10^{-6} \mathrm{M} \mathrm{B}[a] \mathrm{P}$ and their mixture were processed by PCA-LDA, 2-D and 3-D scores plots were derived for visualisation (Figure 4). For gill cells, both 2-D scores and cluster vectors plots show that treatment with $10^{-6} \mathrm{M} \mathrm{B}[a] \mathrm{P}$ led to the most pronounced alterations, mostly associated with the DNA/RNA region, while $\mathrm{C}_{60}$ exerted a lower level of alteration (Figure 4a). However, the 1-D scores plots (see ESI) in the first two LD spaces indicate that co-exposure with these two treatments dramatically reduces their effects in gill cells, but it is still suggestive by the cluster vectors plot that slight genotoxicity was induced (see ESI Table S7). A similar situation occurred in MCF-7 cells (Figure 4b). Cluster vectors plots show that all treatments caused marked alterations in cells including lipids, protein and 


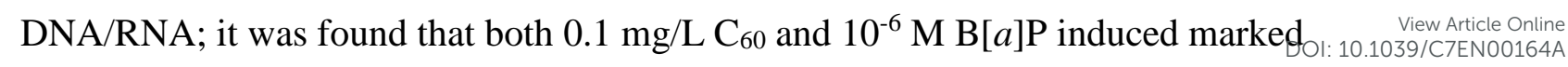
alterations in cells, while treatment with Mix 3 appears relatively limited in its effect. Additionally, the cluster vectors peak shows $\mathrm{C}_{60}$ induced higher alterations in protein rather than in DNA/RNA, while $\mathrm{B}[a] \mathrm{P}$ mostly altered the DNA/RNA region (see ESI Table S8). However, the cluster vectors peak plot suggests that the action of co-exposure is likely to be limited to the lipid and protein region of MCF-7 cells.

Additional analyses were performed to explore the differences in alterations in cells when the binary treatment varied (Dataset $\mathrm{C}_{60}$ mix or Dataset $\mathrm{B}[a] \mathrm{P}$ mix). When gill cells were treated with both $\mathrm{C}_{60}$ and $\mathrm{B}[a] \mathrm{P}$, the alterations were observed to be elevated with decreasing $\mathrm{C}_{60}$ exposure $\left(\mathrm{B}[a] \mathrm{P}\right.$ at $\left.10^{-6} \mathrm{M}\right)$ (Dataset $\mathrm{C}_{60}$ mix, Figure $5 \mathrm{a}$ ). As shown in the cluster vectors plot, the Mix $1\left(\mathrm{C}_{60} 0.001 \mathrm{mg} / \mathrm{L}\right.$ and $\left.\mathrm{B}[a] \mathrm{P} 10^{-6} \mathrm{M}\right)$ caused the most distinct alterations in gill cells, and the effects seem to be a combination of both $\mathrm{C}_{60}$ and $\mathrm{B}[a] \mathrm{P}$, giving enhanced alterations. However, when gill cells were exposed to $\mathrm{C}_{60}$ at $0.1 \mathrm{mg} / \mathrm{L}$ with $\mathrm{B}[a] \mathrm{P}$ at different level, the limited alterations induced by binary exposure were increased with $\mathrm{B}[a] \mathrm{P}$ decreasing (Figure 6a). Additionally, the action of co-exposure in MCF-7 cells appeared to be similar with that in gill cells (Figure $5 \mathrm{~b}$ and $6 \mathrm{~b}$ ). However, higher alterations in the DNA/RNA region were observed in MCF-7 cells than in gill cells, as MCF-7 cells are mammalian and more sensitive to genotoxicity of $\mathrm{B}[a] \mathrm{P}$. Generally, these datasets indicate that high-dose $\mathrm{C}_{60}$ may limit the toxicity of $\mathrm{B}[a] \mathrm{P}$. Table 3 suggests that this might be through attenuation of oxidative damage, although $\mathrm{C}_{60}$ may deliver more $\mathrm{B}[a] \mathrm{P}$ to the cell resulting in elevated CYP1A1 induction (Table 2).

In general, biological effects resulting from binary exposure are difficult to predict ${ }^{54}$. Particularly, when NPs encounter environmental chemical compounds, this issue become more intractable ${ }^{55}$, as more factors come into account ${ }^{56}$. Binary effects of $\mathrm{C}_{60}$ co-exposure 


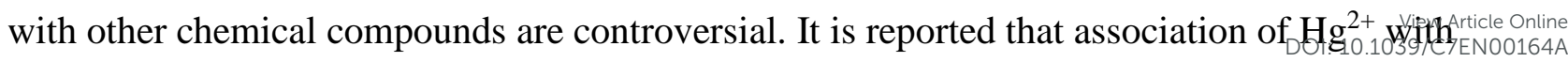
$\mathrm{C}_{60}$ could increase the bioavailability of $\mathrm{Hg}^{2+}$ in zebrafish ${ }^{57}$. Similar investigations also determined that co-exposure with $\mathrm{C}_{60}$ may enhance the effects of organic industrial chemicals $^{58}$. Another study in ZF-L cells that also focused on co-exposure of $\mathrm{C}_{60}$ and $\mathrm{B}[a] \mathrm{P}$ (using one high-dose of $\mathrm{C}_{60}$ at $1.0 \mathrm{mg} / \mathrm{L}$ in co-exposure) suggests that $\mathrm{C}_{60}$ may enhance toxicity by increasing $\mathrm{B}[a] \mathrm{P}$ intake ${ }^{59}$. Other studies draw a different conclusion. It was observed that association between $\mathrm{C}_{60}$ and $\mathrm{EE}_{2}$ reduced $\mathrm{EE}_{2}$ bioavailability in zebrafish ${ }^{60,61}$. Additionally, a reduced histological damage induced by fluoroanthene occurred when coexposed with $\mathrm{C}_{60}$ under UV radiation ${ }^{62}$. Using in vivo models, susceptible target organ based on molecular characteristics such as lipid composition, will need to be identified. ${ }^{63,64}$ Within in vitro models, other underlying mechanisms such as epigenetic alterations can be further investigated $^{65}$. Our results suggest that in some exposure scenarios with a particular endpoint a synergistic response is observed (Table 2), whereas in other cases the response might be additive or individual agents in a binary mixture cancel out each other's effects (Table 3 ). Dis-entangling such complex responses will likely require a systems biology-based approach using "omics" tools" 63 . Herein, the spectral data indicate that low-dose $\mathrm{C}_{60}$ may elevate $\mathrm{B}[a] \mathrm{P}$ toxicity, while high concentration of $\mathrm{C}_{60}$ limit effects. Biospectroscopy also interprets the toxic action mode of such test agents even at low levels, both single and binary treatments. However, the mechanisms underlying the different actions from co-exposure with diverse combinations still requires further investigation.

\section{Acknowledgements}

Funding from the Chinese Academy of Sciences is greatly acknowledged. 
Table 1. Primers used for quantitative real-time RT-PCR analyses

\begin{tabular}{|c|c|c|}
\hline Assay & Name & Sequence $\left(5^{\prime}\right.$ to $\left.>3{ }^{\prime}\right)$ \\
\hline \multirow[t]{2}{*}{$\overline{P 21^{\text {WAFI/CIPI }}}$} & $P 21^{W A F 1 / C I P 1_{-}}-\mathrm{F}$ & GAC CAG CAT GAC AGA TTT CTA CCA \\
\hline & $P 21^{W A F 1 / C I P 1}-\mathrm{R}$ & TTC CTG TGG GCG GAT TAG G \\
\hline \multirow[t]{2}{*}{ CYP1A1 } & CYP1A1-F & ACT TCA TCC CTA TTC TTC GCT ACC T \\
\hline & CYP1A1-R & CGG ATG TGG CCC TTC TCA \\
\hline \multirow[t]{2}{*}{$\beta$-Actin } & $\beta$-Actin-F & CCT GGC ACC CAG CAC AAT \\
\hline & $\beta$-Actin-R & GCC GAT CCA CAC GGA GTA CT \\
\hline
\end{tabular}


Table 2. mRNA transcript levels in MCF-7 cells treated with or without $B[a]$ in the thew $_{9 / C F E N O 0164 A}^{\text {view }}$ presence or absence of $\mathrm{C}_{60}$ fullerene

\begin{tabular}{|c|c|c|}
\hline \multirow[b]{2}{*}{ Treatment } & \multicolumn{2}{|c|}{ Relative expression levels } \\
\hline & $P 21^{W A F 1 / C I P 1}$ & CYPIAl \\
\hline Vehicle control & 1 (C) & 1 (C) \\
\hline $0.01 \mathrm{M} \mathrm{B}[a] \mathrm{P}$ & $1.3 \pm 0.3$ & $1.9 \pm 0.2$ \\
\hline $\mathrm{C}_{60}$ fullerene & $1.9 \pm 0.3$ & $1.5 \pm 0.3$ \\
\hline $0.01 \mathrm{M} \mathrm{B}[a] \mathrm{P}+0.1 \mathrm{mg} / \mathrm{L} \mathrm{C}_{60}$ fullerene & $7.4 \pm 1.9$ & $21.1 \pm 5.8$ \\
\hline \multicolumn{3}{|c|}{$\begin{array}{l}\text { (C), calibrator, which for the purposes of these experiments were vehicle controls. MCF-7 cells } \\
\text { in aliquots of complete medium }\left(5 \mathrm{ml}, \approx 1 \times 10^{5} \text { cells) were seeded into } 60 \text {-mm Petri dishes. }\right. \\
\text { Following reverse transcription of total RNA, quantitative real-time RT-PCR was carried out. } \\
\text { Results are the means } \pm \text { SD of three separate experiments. Each experimental medium } \\
\text { contained a final level of } 0.1 \% \text { (vol/vol) } 1 \% \text { BSA solution and DMSO. }\end{array}$} \\
\hline
\end{tabular}


2 3 4 5

Table 3. Oxidative damage in MCF-7 cells treated with or without $\mathrm{B}[a] \mathrm{P}$ in the presenged

\section{or absence of $\mathrm{C}_{60}$ fullerene}

\begin{tabular}{ccc}
\hline & \multicolumn{2}{c}{ Lipid peroxidation levels } \\
\cline { 2 - 3 } Treatment & TBARS & DCF fluorescence \\
& $(\mathrm{nmol} / \mathrm{mg}$ & (arbitrary units) \\
& protein) & \\
\hline Vehicle control & $99.1 \pm 46.0$ & $203.6 \pm 33.5$ \\
$0.01 \mathrm{M} \mathrm{B}[a] \mathrm{P}$ & $143.9 \pm 48.1$ & $276.0 \pm 30.3$ \\
$0.1 \mathrm{mg} / \mathrm{L} \mathrm{C} 60$ fullerene & $200.6 \pm 90.0$ & $306.1 \pm 52.0$ \\
$0.01 \mathrm{M} \mathrm{B}[a] \mathrm{P}+0.1 \mathrm{mg} / \mathrm{L} \mathrm{C}_{60}$ fullerene & $106.14 \pm 15.7$ & $200.6 \pm 35.7$ \\
\hline
\end{tabular}

Routinely cultured MCF-7 cells were disaggregated and re-suspended in complete medium (DMEM, 10\% FCS) prior to seeding aliquots $\left(10 \mathrm{ml}, \approx 1 \times 10^{6}\right.$ cells) into $75 \mathrm{~cm}^{2}$ flasks. Following 24-h incubation, cells were treated for a further $24 \mathrm{~h} 10^{-8} \mathrm{M} \mathrm{B}[a] \mathrm{P}, 0.1 \mathrm{mg} / \mathrm{L} \mathrm{C} 60$ fullerene or a combination of both; a vehicle control was also included. Levels of lipid peroxidation were determined using the TBARS assay. Relative fluorescence intensity was quantified by flow cytometry, using DCFH-DA as a probe. Results are the means \pm SD of five separate experiments, each performed in duplicate. Each experimental medium contained a final level of $0.1 \%$ (vol/vol) $1 \%$ BSA solution and DMSO 


\section{References}

1. A. Kahru and H.-C. Dubourguier, From ecotoxicology to nanoecotoxicology, Toxicology, 2010, 269 (2-3), 105-119.

2. K. Savolainen, H. Alenius, H. Norppa, T. Tuomi and G. Kasper, Risk assessment of engineered nanomaterials and nanotechnologies--a review, Toxicology, 2010, 269 (2-3), 92104.

3. N. A. Monteiro-Riviere, A. O. Inman and L. W. Zhang, Limitations and relative utility of screening assays to assess engineered nanoparticle toxicity in a human cell line, Toxicol. Appl. Pharmacol., 2009, 234 (2), 222-235.

4. M. Crane, R. Handy, J. Garrod and R Owen, Ecotoxicity test methods and environmental hazard assessment for engineered nanoparticles, Ecotoxicology, 2008, 17 (5), 421-437.

5. M. Hassellöv, J. Readman, J. Ranville and K. Tiede, Nanoparticle analysis and characterization methodologies in environmental risk assessment of engineered nanoparticles, Ecotoxicology, 2008, 17 (5), 344-361.

6. K. Aschberger, C. Micheletti, B. Sokull-Klüttgen and F. M. Christensen, Analysis of currently available data for characterising the risk of engineered nanomaterials to the environment and human health - Lessons learned from four case studies, Environ. Int., 2011, 37 (6), 1143-1156.

7. G. A. Hughes, Nanostructure-mediated drug delivery, Nanomed. Nanotechnol. Biol. Med., 2005, 1 (1), 22-30.

8. R. Singh and J. W. Lillard Jr, Nanoparticle-based targeted drug delivery, Exp. Mol. Pathol., 2009, 86 (3), 215-223.

9. A. Montellano, T. Da Ros, A. Bianco and M. Prato, Fullerene $\mathrm{C}_{60}$ as a multifunctional system for drug and gene delivery, Nanoscale, 2011, 3 (10), 4035-4041.

10. T. Y. Zakharian, A. Seryshev, B. Sitharaman, B. E. Gilbert, V. Knight and L. J. Wilson, A Fullerene-Paclitaxel Chemotherapeutic: Synthesis, Characterization, and Study of Biological Activity in Tissue Culture, J. Am. Chem. Soc., 2005, 127 (36), 12508-12509. 
11. K. Aschberger, H. J. Johnston, V. Stone, R. J. Aitken, C. L. Tran, S. M. Hanking, YS Siev/Article Online

K. Peters and F. M. Christensen, Review of fullerene toxicity and exposure - Appraisal of a human health risk assessment, based on open literature, Regul. Toxicol. Pharmacol., 2010, 58 (3), 455-473.

12. P. Spohn, C. Hirsch, F. Hasler, A. Bruinink, H. F. Krug and P. Wick, $\mathrm{C}_{60}$ fullerene: A powerful antioxidant or a damaging agent? The importance of an in-depth material characterization prior to toxicity assays, Environ. Pollut., 2009, 157 (4), 1134-1139.

13. X. R. Xia, N. A. Monteiro-Riviere and J. E. Riviere, Intrinsic biological property of colloidal fullerene nanoparticles $\left(\mathrm{nC}_{60}\right)$ : Lack of lethality after high dose exposure to human epidermal and bacterial cells, Toxicol. Lett., 2010, 197 (2), 128-134.

14. P. Christian, F. Von der Kammer, M. Baalousha and T Hofmann, Nanoparticles: structure, properties, preparation and behaviour in environmental media, Ecotoxicology, 2008, 17 (5), 326-343.

15. L. K. Limbach, P. Wick, P. Manser, R. N. Grass, A. Bruinink and W. J. Stark, Exposure of Engineered Nanoparticles to Human Lung Epithelial Cells: Influence of Chemical Composition and Catalytic Activity on Oxidative Stress, Environ. Sci. Technol., 2007, 41 (11), 4158-4163.

16. W. Fan, M. Cui, H. Liu, C. Wang, Z. Shi, C. Tan and X. Yang, Nano-TiO 2 enhances the toxicity of copper in natural water to Daphnia magna, Environ. Pollut., 2011, 159 (3), 729-734.

17. B. Pan and B. Xing, Adsorption Mechanisms of Organic Chemicals on Carbon Nanotubes, Environ. Sci. Technol., 2008, 42 (24), 9005-9013.

18. B. Pan, D. Lin, H. Mashayekhi and B. Xing, Adsorption and Hysteresis of Bisphenol A and 17 $\alpha$-Ethinyl Estradiol on Carbon Nanomaterials, Environ. Sci. Technol., 2008, 42 (15), $5480-5485$.

19. X. Li, B. Gámiz, Y. Wang, J. J. Pignatello and B. Xing, Competitive Sorption Used To Probe Strong Hydrogen Bonding Sites for Weak Organic Acids on Carbon Nanotubes, Environ. Sci. Technol., 2015, 49 (3), 1409-1417. 
20. Y. Su, X. Yan, Y. Pu, F. Xiao, D. Wang and M. Yang, Risks of Single-Walled Caablobthicle Online Nanotubes Acting as Contaminants-Carriers: Potential Release of Phenanthrene in Japanese Medaka (Oryzias latipes), Environ. Sci. Technol., 2013, 47 (9), 4704-4710.

21. M. Song, F. Wang, L. Zeng, J. Yin, H. Wang and G. Jiang, Co-exposure of CarboxylFunctionalized Single-Walled Carbon Nanotubes and 17 $\alpha$-Ethinylestradiol in Cultured Cells: Effects on Bioactivity and Cytotoxicity, Environ. Sci. Technol., 2014, 48 (23), 13978-13984.

22. K. Srogi, Monitoring of environmental exposure to polycyclic aromatic hydrocarbons: a review, Environ. Chem. Lett., 2007, 5 (4), 169-195.

23. K. W. Bock, Aryl hydrocarbon or dioxin receptor: Biologic and toxic responses. In Reviews of Physiology, Biochemistry and Pharmacology, Springer Berlin Heidelberg: 1994, Vol. 125, pp 1-42.

24. W. M. Baird, L. A. Hooven and B. Mahadevan, Carcinogenic polycyclic aromatic hydrocarbon-DNA adducts and mechanism of action, Environ. Mol. Mutagen., 2005, 45 (2-3), 106-114.

25. W. Xue and D. Warshawsky, Metabolic activation of polycyclic and heterocyclic aromatic hydrocarbons and DNA damage: A review, Toxicol. Appl. Pharmacol., 2005, 206 (1), 73-93.

26. D. W. Nebert and T. P. Dalton, The role of cytochrome P450 enzymes in endogenous signalling pathways and environmental carcinogenesis, Nat. Rev. Cancer, 2006, 6 (12), 947960.

27. M. J. Baker, J. Trevisan, P. Bassan, R Bhargava, H. J. Butler, K. M. Dorling, P. R. Fielden, S. W. Fogarty, N. J. Fullwood, K. A. Heys, C Hughes, P. Lasch, P. L. Martin-Hirsch, B. Obinaju, G. D. Sockalingum, J. Sulé-Suso, R. J. Strong, M. J. Walsh, B. R. Wood, P. Gardner, and F. L. Martin, Using Fourier transform IR spectroscopy to analyze biological materials, Nat. Protoc., 2014, 9 (8), 1771-1791.

28. D. I. Ellis and R. Goodacre, Metabolic fingerprinting in disease diagnosis: biomedical applications of infrared and Raman spectroscopy, Analyst, 2006, 131 (8), 875-885.

29. M. J. Walsh, T. G. Fellous, A. Hammiche, W.-R. Lin, N. J. Fullwood, O. Grude, F. Bahrami, J. M. Nicholson, M. Cotte, J. Susini, H. M. Pollock, M. Brittan, P. L. Martin-Hirsch, 
M. R. Alison and F. L. Martin, Fourier Transform Infrared Microspectroscopy Identifies. View Article Online Symmetric $\mathrm{PO}_{2}{ }^{-}$Modifications as a Marker of the Putative Stem Cell Region of Human Intestinal Crypts, Stem Cells, 2008, 26 (1), 108-118.

30. L. Corte, P. Rellini, L. Roscini, F. Fatichenti and G. Cardinali, Development of a novel, FTIR (Fourier transform infrared spectroscopy) based, yeast bioassay for toxicity testing and stress response study, Anal. Chim. Acta, 2010,659 (1-2), 258-265.

31. J. G. Kelly, J. Trevisan, A. D. Scott, P. L. Carmichael, H. M. Pollock, P. L. MartinHirschand F. L. Martin, Biospectroscopy to metabolically profile biomolecular structure: a multistage approach linking computational analysis with biomarkers, J. Proteome Res., 2011, 10 (4), 1437-1448.

32. W. Pang, J. Li, A. A. Ahmadzai, L. D. Heppenstall, V. Llabjani, J. Trevisan, X. Qiu and F. L. Martin, Identification of benzo[a]pyrene-induced cell cycle-associated alterations in MCF-7 cells using infrared spectroscopy with computational analysis, Toxicology, 2012, 298 (1-3), 24-29.

33. J. Li, R. Strong, J. Trevisan, S. W. Fogarty, N. J. Fullwood, K. C. Jones and F. L. Martin, Dose-Related Alterations of Carbon Nanoparticles in Mammalian Cells Detected Using Biospectroscopy: Potential for Real-World Effects, Environ. Sci. Technol., 2013, 47 (17), 10005-10011.

34. P. A. Walker, N. R. Bury and C. Hogstrand, Influence of Culture Conditions on Metal-Induced Responses in a Cultured Rainbow Trout Gill Epithelium, Environ. Sci. Technol., 2007, 41 (18), 6505-6513.

35. K. Schirmer, A. G. J. Chan, B. M. Greenberg, D. G. Dixon and N. C. Bols, Methodology for demonstrating and measuring the photocytotoxicity of fluoranthene to fish cells in culture, Toxicol. In Vitro, 1997, 11 (1-2), 107-119.

36. K. Tanneberger, A. Rico-Rico, N. I. Kramer, F. J. M. Busser, J. L. M. Hermens and K. Schirmer, Effects of Solvents and Dosing Procedure on Chemical Toxicity in Cell-Based in Vitro Assays, Environ. Sci. Technol., 2010, 44 (12), 4775-4781.

37. R. Gautam, S. Vanga, F. Ariese and S. Umapathy, Review of multidimensional data processing approaches for Raman and infrared spectroscopy, EPJ Techn. Instrum., 2015, 2 (1), 1-38. 
38. V. Llabjani, J. Trevisan, K. C. Jones, R. F. Shore and F. L. Martin, Derivation by View Article Online Infrared Spectroscopy with Multivariate Analysis of Bimodal Contaminant-Induced DoseResponse Effects in MCF-7 Cells, Environ. Sci. Technol., 2011, 45 (14), 6129-6135.

39. V. Llabjani, J. D. Crosse, A. A. Ahmadzai, I. I. Patel, W. Pang, J. Trevisan, K. C. Jones, R. F. Shore and F. L. Martin, Differential Effects in Mammalian Cells Induced by Chemical Mixtures in Environmental Biota As Profiled Using Infrared Spectroscopy, Environ. Sci. Technol., 2011, 45 (24), 10706-10712.

40. H. Jiao, S. L. Allinson, M. J. Walsh, R. Hewitt, K. J. Cole, D. H. Phillips and F. L. Martin, Growth kinetics in MCF-7 cells modulate benzo[a]pyrene-induced CYP1A1 upregulation, Mutagenesis, 2007, 22 (2), 111-116.

41. P. Nusuetrong, T. Pengsuparp, D. Meksuriyen, M. Tanitsu, H. Kikuchi, M. Mizugaki, K. Shimazu, Y. Oshima, N. Nakahata and M. Yoshida, Satratoxin H generates reactive oxygen species and lipid peroxides in PC12 cells, Biol. Pharm. Bull., 2008, 31 (6), 11151120.

42. Y. I. Prylutskyy, I. V. Vereshchaka, A. V. Maznychenko, N. V. Bulgakova, O. O. Gonchar, O. A Kyzyma, U. Ritter, P. Scharff, T. Tomiak, D. M. Nozdrenko, I. V.

Mishchenko and A. I. Kostyukov, $\mathrm{C}_{60}$ fullerene as promising therapeutic agent for correcting and preventing skeletal muscle fatigue, J. Nanobiotechnol., 2017, 15, 8.

43. P. G. Andrus, Cancer monitoring by FTIR spectroscopy, Technol. Cancer Res. Treat., 2006, 5, (2), 157-167.

44. R. K. Sahu, S. Argov, A. Salman, M. Huleihel, N. Grossman, Z. Hammody, J. Kapelushnik and S. Mordechai, Characteristic Absorbance of Nucleic Acids in the Mid-IR Region as Possible Common Biomarkers for Diagnosis of Malignancy, Technol. Cancer Res. Treat., 2004, 3 (6), 629-638.

45. J. R. Mourant, Y. R. Yamada, S. Carpenter, L. R. Dominique and J. P. Freyer, FTIR Spectroscopy Demonstrates Biochemical Differences in Mammalian Cell Cultures at Different Growth Stages, Biophys. J., 2003, 85 (3), 1938-1947.

46. L. Wang and B. Mizaikoff, Application of multivariate data-analysis techniques to biomedical diagnostics based on mid-infrared spectroscopy, Anal. Bioanal. Chem., 2008, 391 (5), 1641-1654. 


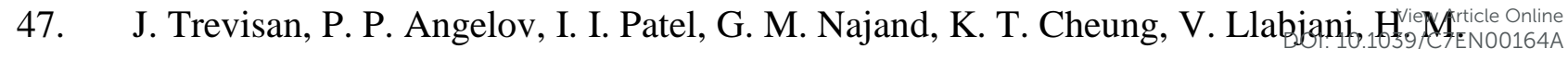
Pollock, S. W. Bruce, K. Pant, P. L. Carmichael, A. D. Scott and F. L. Martin, Syrian hamster embryo (SHE) assay (pH 6.7) coupled with infrared spectroscopy and chemometrics towards toxicological assessment, Analyst, 2010, 135 (12), 3266-3272.

48. J. Trevisan, P. P. Angelov, P. L. Carmichael, A. D. Scott and F.L. Martin, Extracting biological information with computational analysis of Fourier-transform infrared (FTIR) biospectroscopy datasets: current practices to future perspectives, Analyst, 2012, 137 (14), 3202-3215.

49. C. M. Sayes, A. M. Gobin, K. D. Ausman, J. Mendez, J. L. West and V. L. Colvin, Nano- $\mathrm{C}_{60}$ cytotoxicity is due to lipid peroxidation, Biomaterials, 26, 7587-7595.

50. A. Dhawan, J. S. Taurozzi, A. K. Pandey, W. Shan, S. M. Miller, S. Hashsham and V. V. Tarabara, Stable Colloidal Dispersions of C60 Fullerenes in Water: Evidence for Genotoxicity. Environ. Sci. Technol., 2006, 40 (23), 7394-7401.

51. J. K. Folkmann, L. Risom, N. R. Jacobsen, H. Wallin, S. Loft and P. Møller, Oxidatively damaged DNA in rats exposed by oral gavage to C60 fullerenes and singlewalled carbon nanotubes, Environ. Health Perspect., 2009, 117 (5), 703-708.

52. F. Wang, C. Jin, H. Liang, Y. Tang, H. Zhang and Y. Yang, Effects of fullerene $\mathrm{C}_{60}$ nanoparticles on A549 cells, Environ. Toxicol. Pharmacol., 2014, 37 (2), 656-661.

53. A. Castaño and C. Becerril, In vitro assessment of DNA damage after short- and longterm exposure to benzo(a)pyrene using RAPD and the RTG-2 fish cell line, Mutat. Res., 2004, 552 (1-2), 141-151.

54. V. Llabjani, J. Trevisan, K. C. Jones, R. F. Shore and F. L. Martin, Binary Mixture Effects by PBDE Congeners (47, 153, 183, or 209) and PCB Congeners (126 or 153) in MCF-7 Cells: Biochemical Alterations Assessed by IR Spectroscopy and Multivariate Analysis, Environ. Sci. Technol., 2010, 44 (10), 3992-3998.

55. L. Canesi, C. Ciacci and T. Balbi, Interactive effects of nanoparticles with other contaminants in aquatic organisms: Friend or foe? Mar. Environ. Res., 2015, 111, 128-134. 
56. A. Baun, S. N. Sørensen, R. F. Rasmussen, N. B. Hartmann and C. B. Kocb, Toxicicituryticle Online and bioaccumulation of xenobiotic organic compounds in the presence of aqueous suspensions of aggregates of nano-C 60 , Aquat. Toxicol., 2008, 86 (3), 379-387.

57. T. B. Henry, S. J. Wileman, H. Boran and P. Sutton, Association of $\mathrm{Hg}^{2+}$ with Aqueous $\left(\mathrm{C}_{60}\right) \mathrm{n}$ Aggregates Facilitates Increased Bioavailability of $\mathrm{Hg}^{2+}$ in Zebrafish (Danio rerio), Environ. Sci. Technol., 2013, 47 (17), 9997-10004.

58. M. Lehto, T. Karilainen, T. Róg, O. Cramariuc, E. Vanhala, J. Tornaeus, H. Taberman, J. Jänis, H. Alenius, I. Vattulainen and O. Laine, Co-Exposure with Fullerene May Strengthen Health Effects of Organic Industrial Chemicals, PLoS ONE, 2014, 9 (12), e114490.

59. J. L. R. Ferreira, M. N. Lonné, T. A. França, N. R. Maximilla, T. H. Lugokenski, P. G. Costa, G. Fillmann, F. A. Antunes Soares, F. R. de la Torre and J. M. Monserrat, J. M., Coexposure of the organic nanomaterial fullerene $\mathrm{C}_{60}$ with benzo[a]pyrene in Danio rerio (zebrafish) hepatocytes: Evidence of toxicological interactions, Aquat. Toxicol., 2014, 147, 76-83.

60. J.-W. Park, T. B. Henry, F.-M. Menn, R. N. Compton and G. Sayler, No bioavailability of $17 \alpha$-ethinylestradiol when associated with $\mathrm{nC}_{60}$ aggregates during dietary exposure in adult male zebrafish (Danio rerio), Chemosphere, 2010, 81 (10), 1227-1232.

61. J.-W. Park, T. B. Henry, S. Ard, F.-M. Menn, R. N. Compton and G. S. Sayler, The association between $\mathrm{nC}_{60}$ and $17 \alpha$-ethinylestradiol (EE2) decreases EE2 bioavailability in zebrafish and alters nanoaggregate characteristics, Nanotoxicology, 2011, 5 (3), 406-416.

62. X. Y. Yang, R. E. Edelmann and J. T. Oris, Suspended $\mathrm{C}_{60}$ nanoparticles protect against short-term UV and fluoranthene photo-induced toxicity, but cause long-term cellular damage in Daphnia magna, Aquat. Toxicol., 2010, 100 (2), 202-210.

63. E. Gorrochategui, J. Li, N. J. Fullwood, G. G. Ying, M. Tian, L. Cui, H. Shen, S. Lacorte, R. Tauler and F. L. Martin, Diet-sourced carbon-based nanoparticles induce lipid alterations in tissues of zebrafish (Danio rerio) with genomic hypermethylation changes in brain, Mutagenesis, 2017, 32 (1), 91-103. 
64. J. Li, G. G. Ying, K. C. Jones and F. L. Martin, Real-world carbon nanoparticlele $\begin{gathered}\text { View Article Online } \\ \text { 6.1039/C7ENO0164A }\end{gathered}$ exposures induce brain and gonadal alterations in zebrafish (Danio rerio) as determined by biospectroscopy techniques, Analyst, 140 (8), 2687-2695.

65. J. Li, M. Tian, L. Cui, J. Dwyer, N. J. Fullwood, H. Shen and F. L. Martin, Low-dose carbon-based nanoparticle-induced effects in A549 lung cells determined by biospectroscopy are associated with increases in genomic methylation. Sci. Rep., 2016, 6, 20207. 


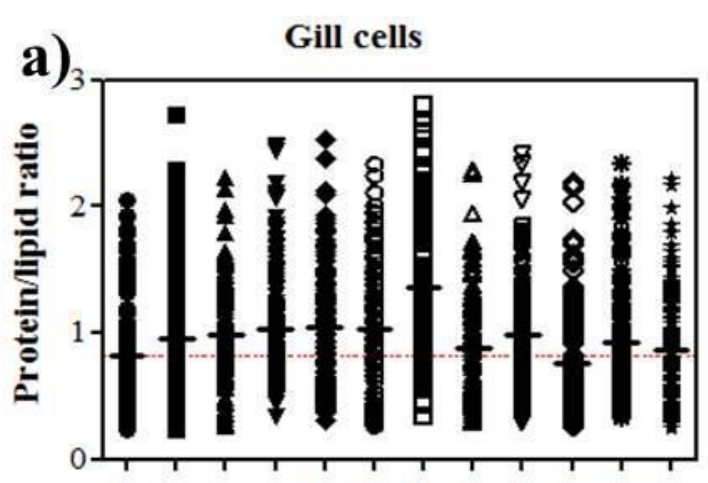

MCF-7

DOI: $10.1039 /(2010$
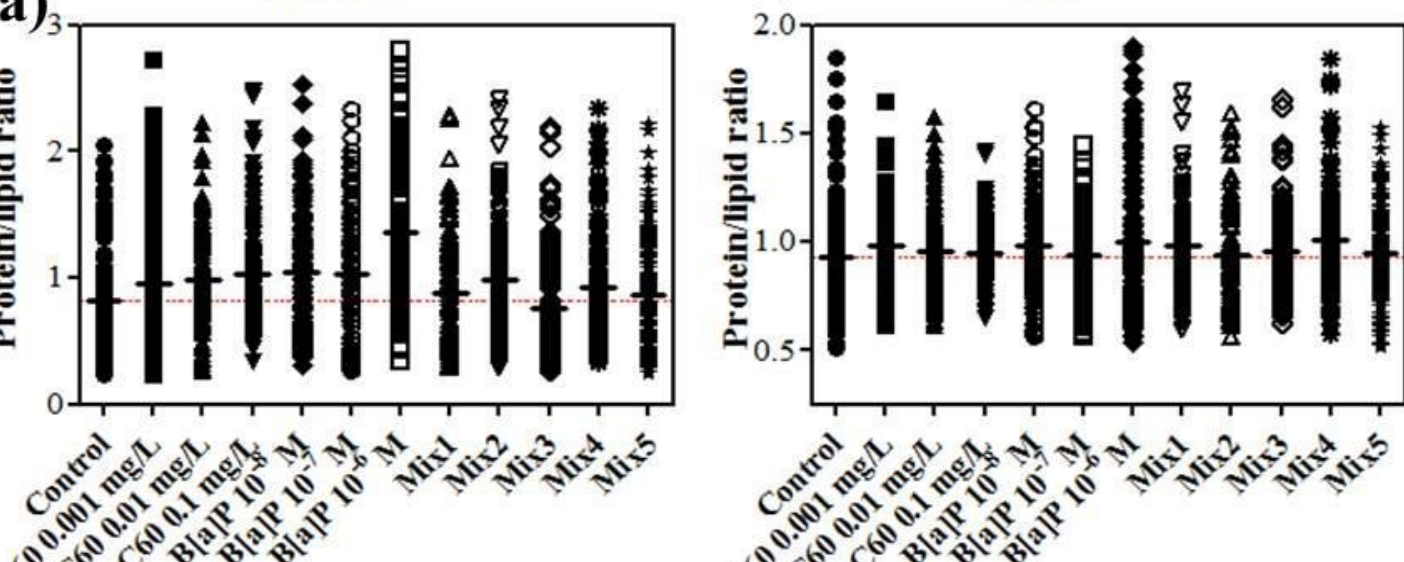

$6^{\circ} c^{\circ} c^{\circ}$ के

b)

Gill cells
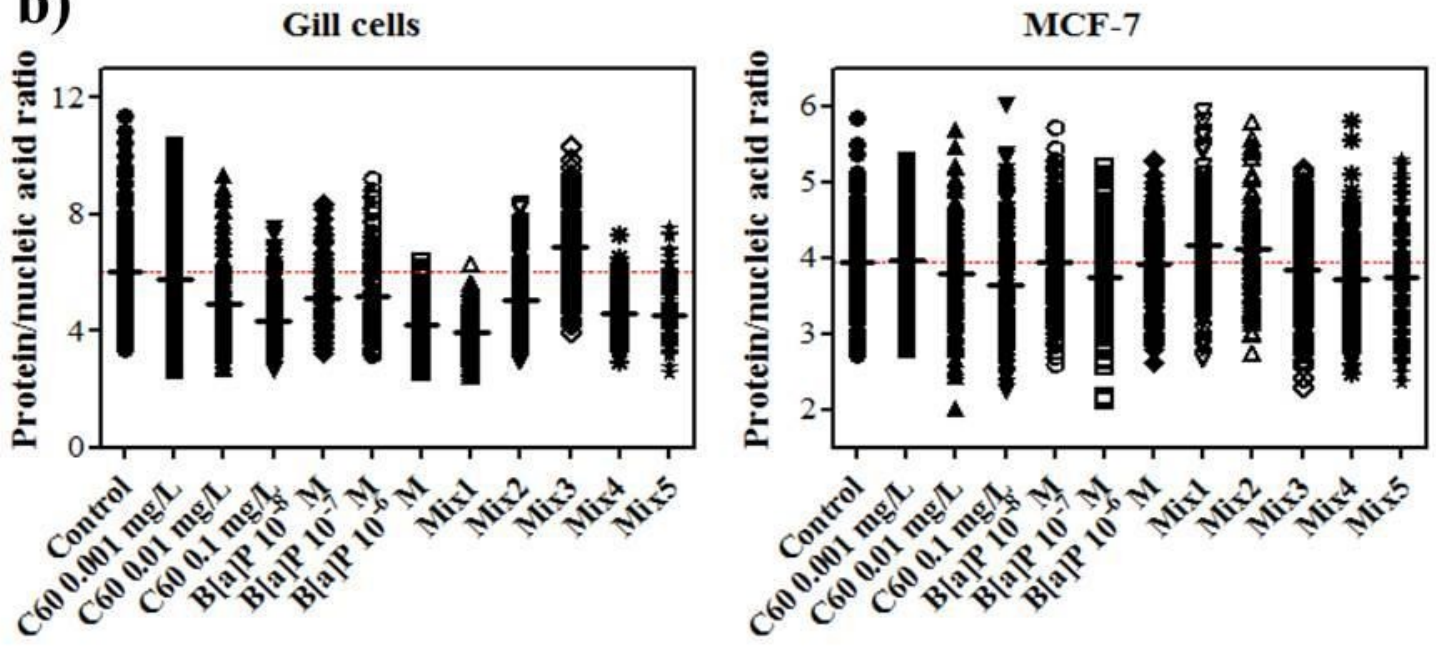

c)

Gill cells

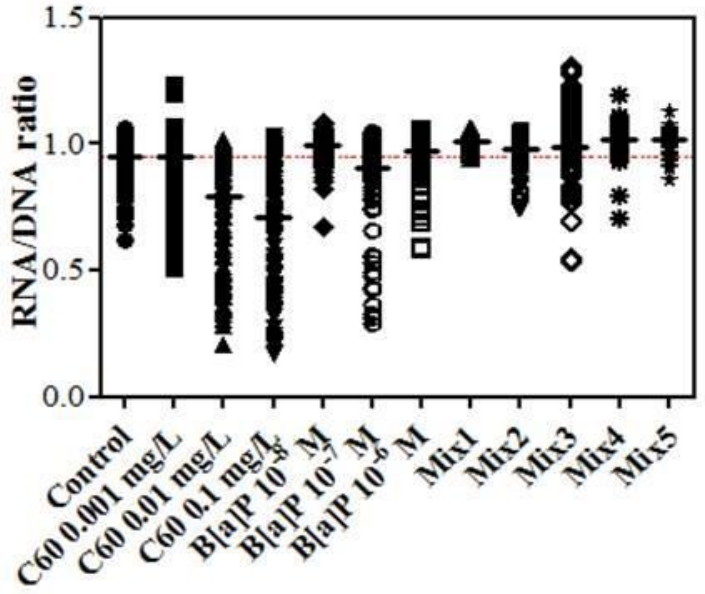

MCF-7

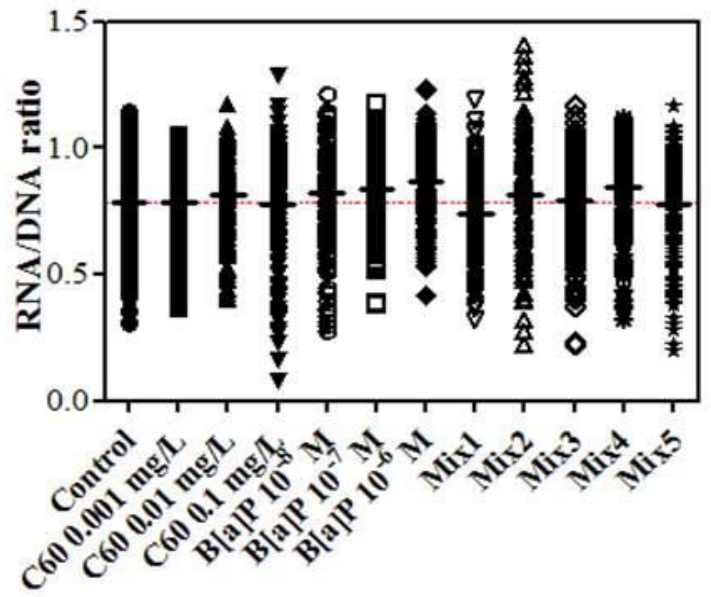

Figure 1 Intensity absorbance ratio derived from IR spectra of the cells: $a$ ) Ratio of proteinto-lipid; $\boldsymbol{b}$ ) Ratio of protein-to-nucleic acid; and, $\boldsymbol{c}$ ) Ratio of RNA-to-DNA. 

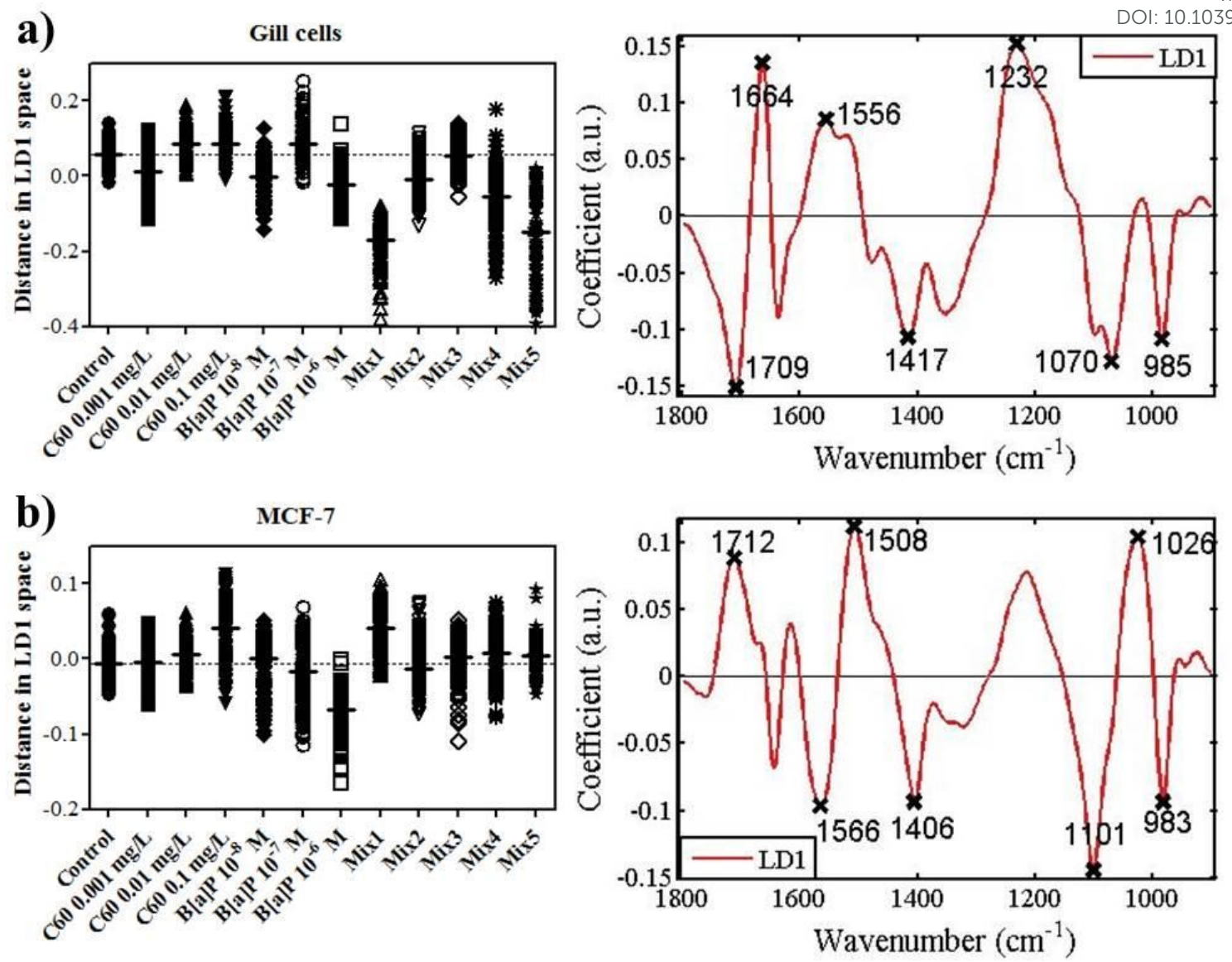

Figure 2 One-D scores plot in LD1 derived from PCA-LDA of spectral dataset (Dataset Total), with corresponding loadings plot: $\boldsymbol{a}$ ) Gill cells; and, b) MCF-7 cells. 

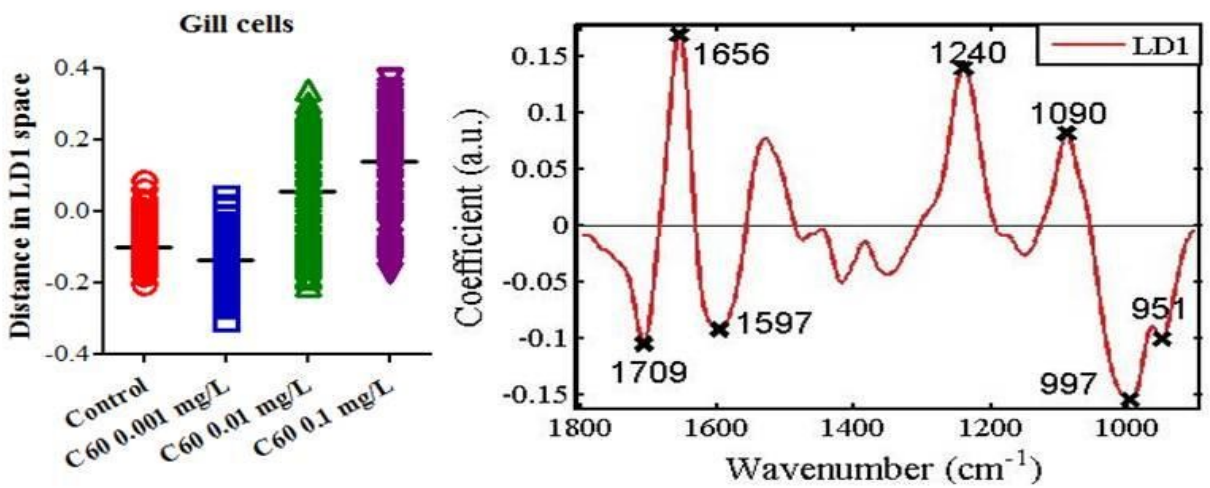

View Article Online

Gill cells
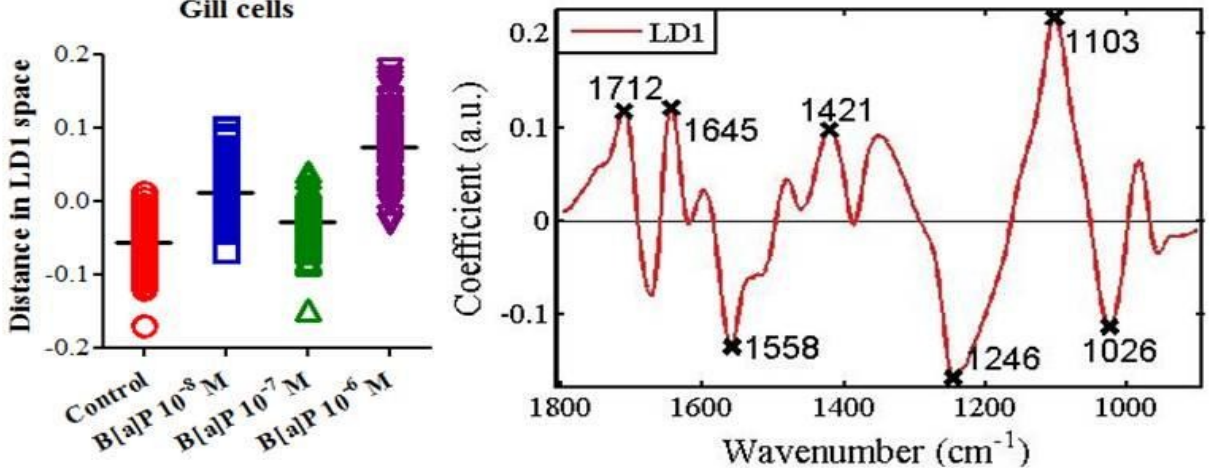

MCF-7
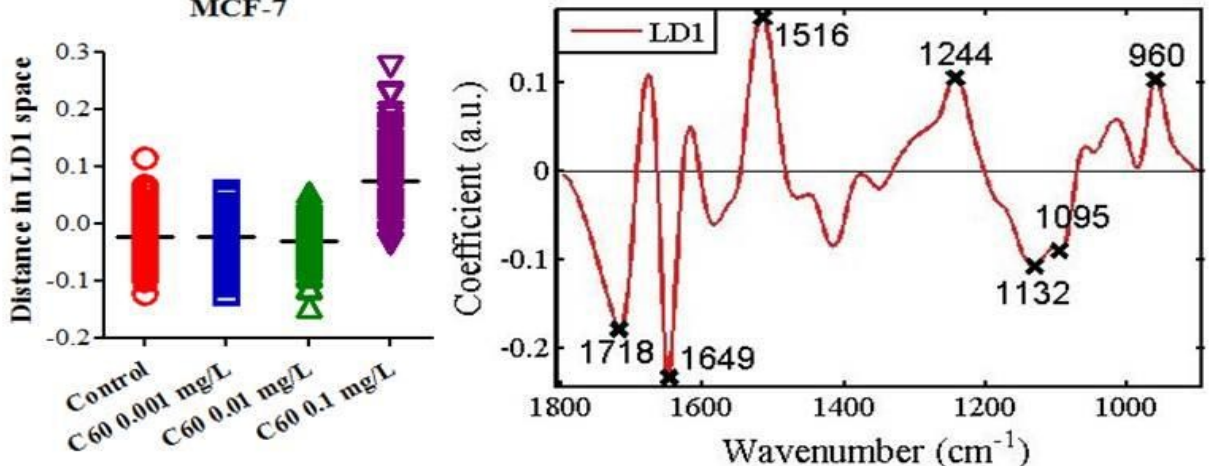

MCF-7
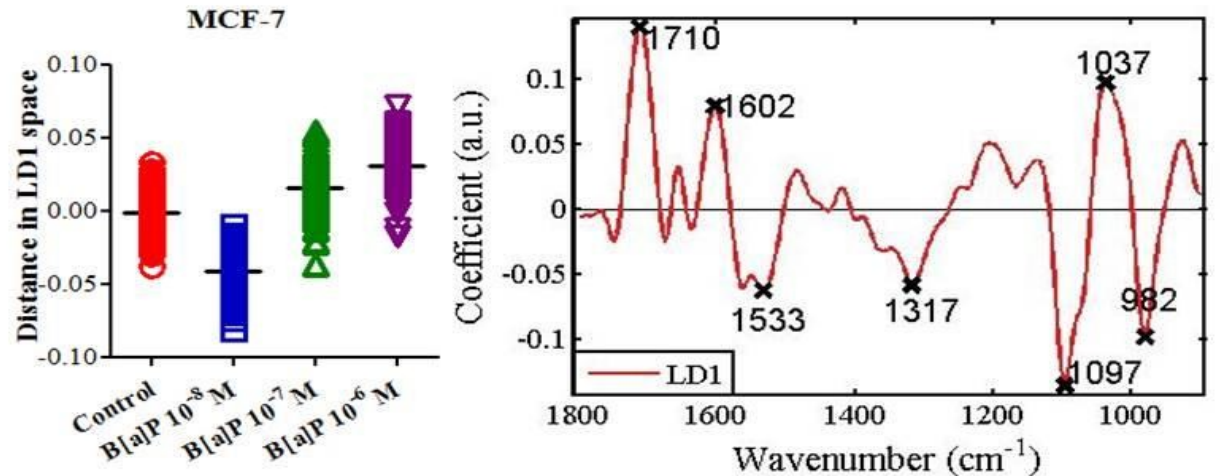

Figure 3 One-D scores plot in LD1 derived from PCA-LDA of spectral dataset for single treatment, with corresponding loadings plot. 

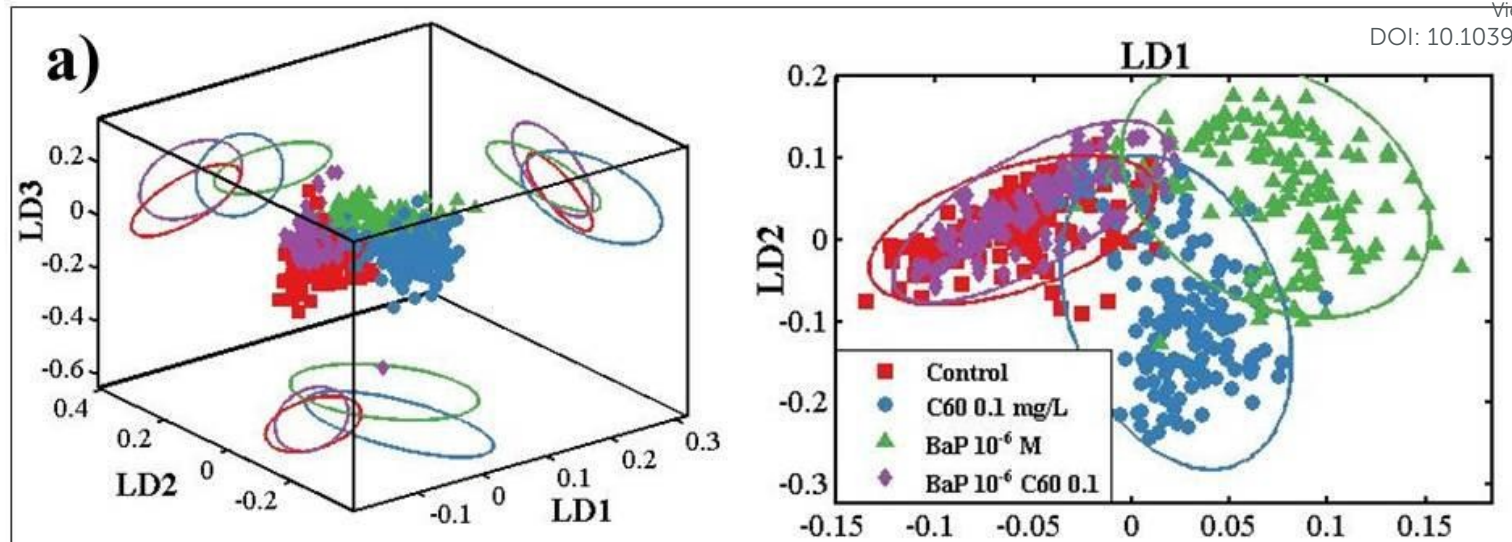

Gill cells
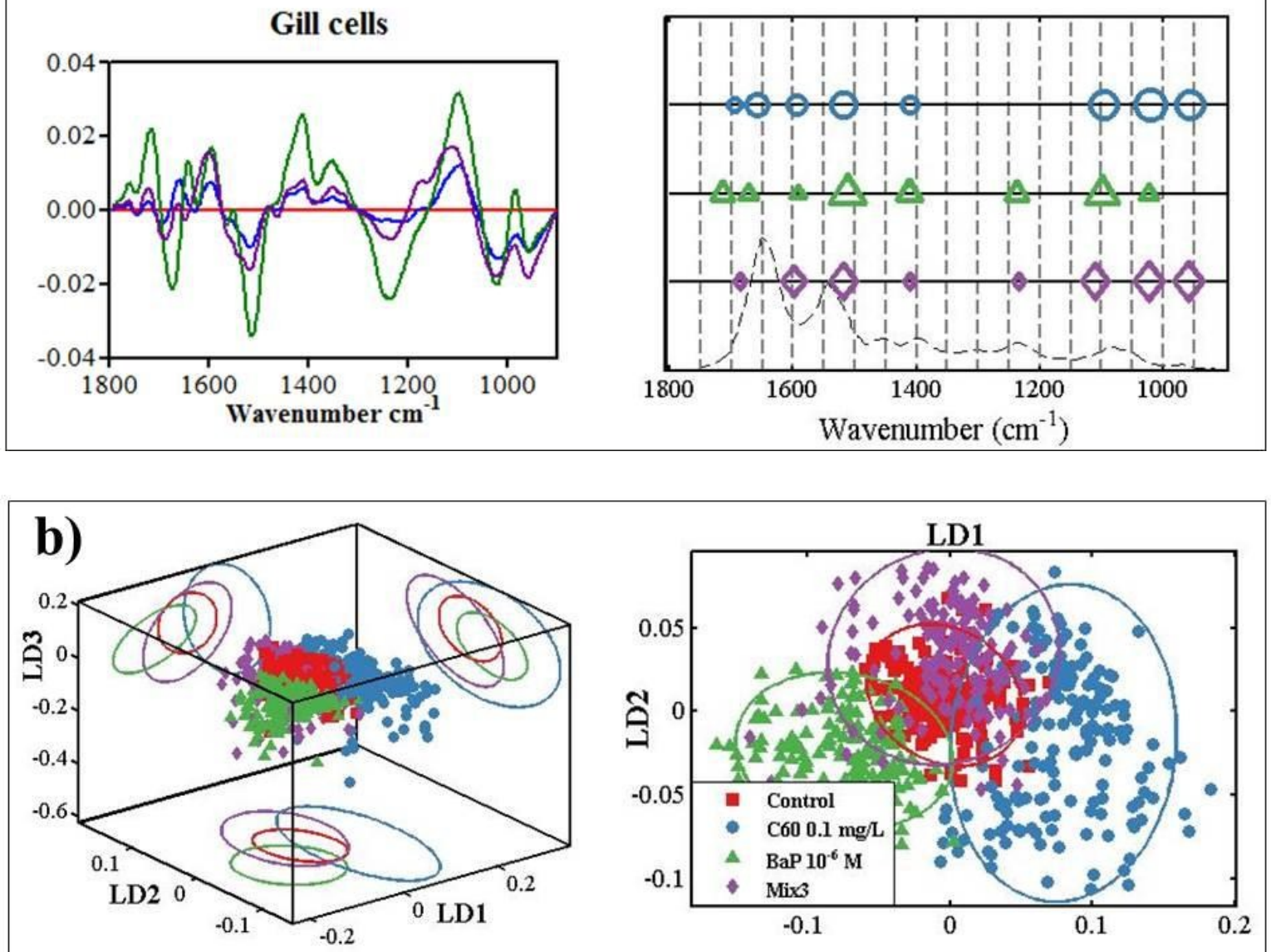

MCF-7
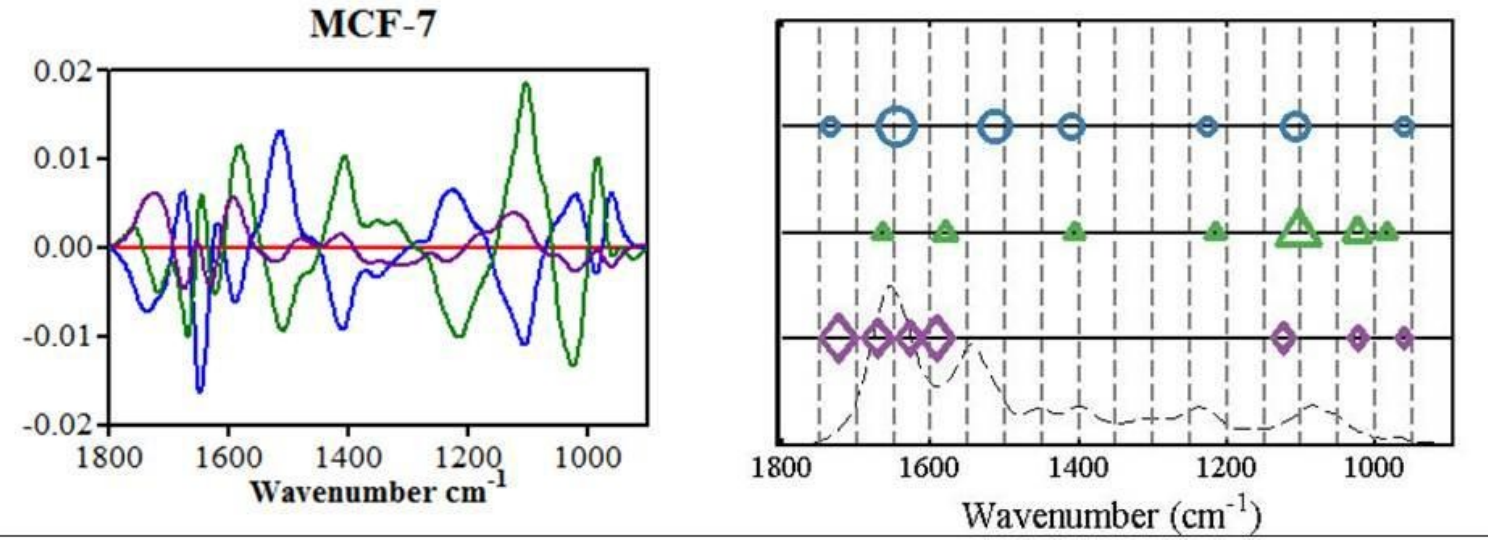

Figure 4 Scores plot and cluster vector derived from PCA-LDA of spectral dataset (Dataset mix). a) Gill cells; and, b) MCF-7 cells. 

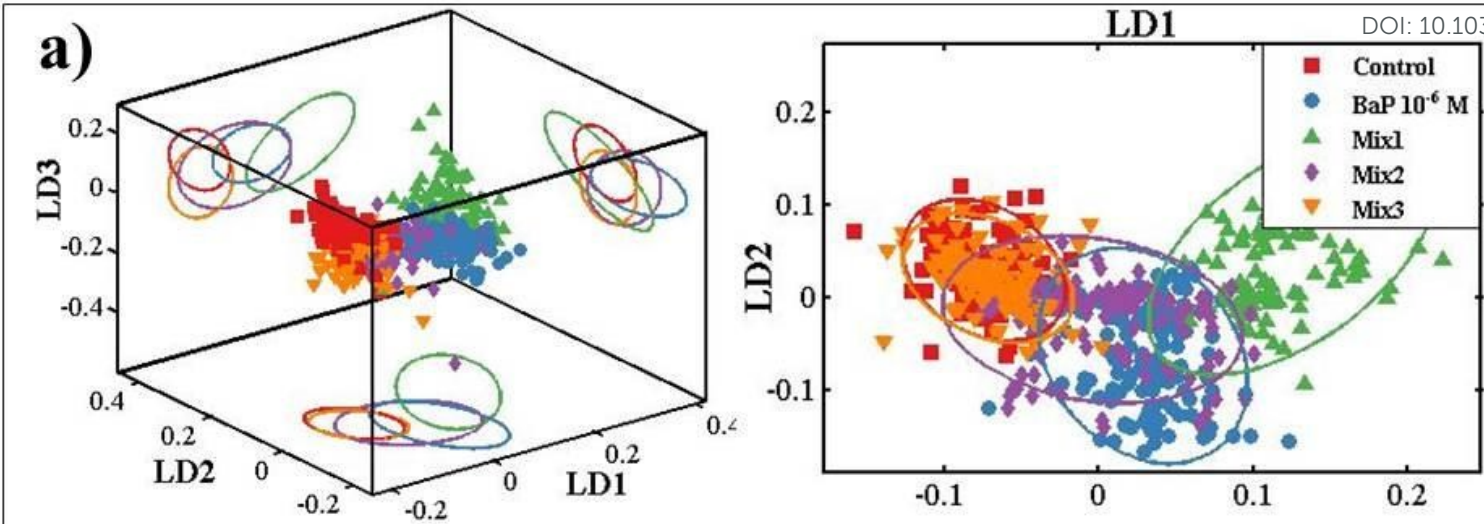

Gill cells
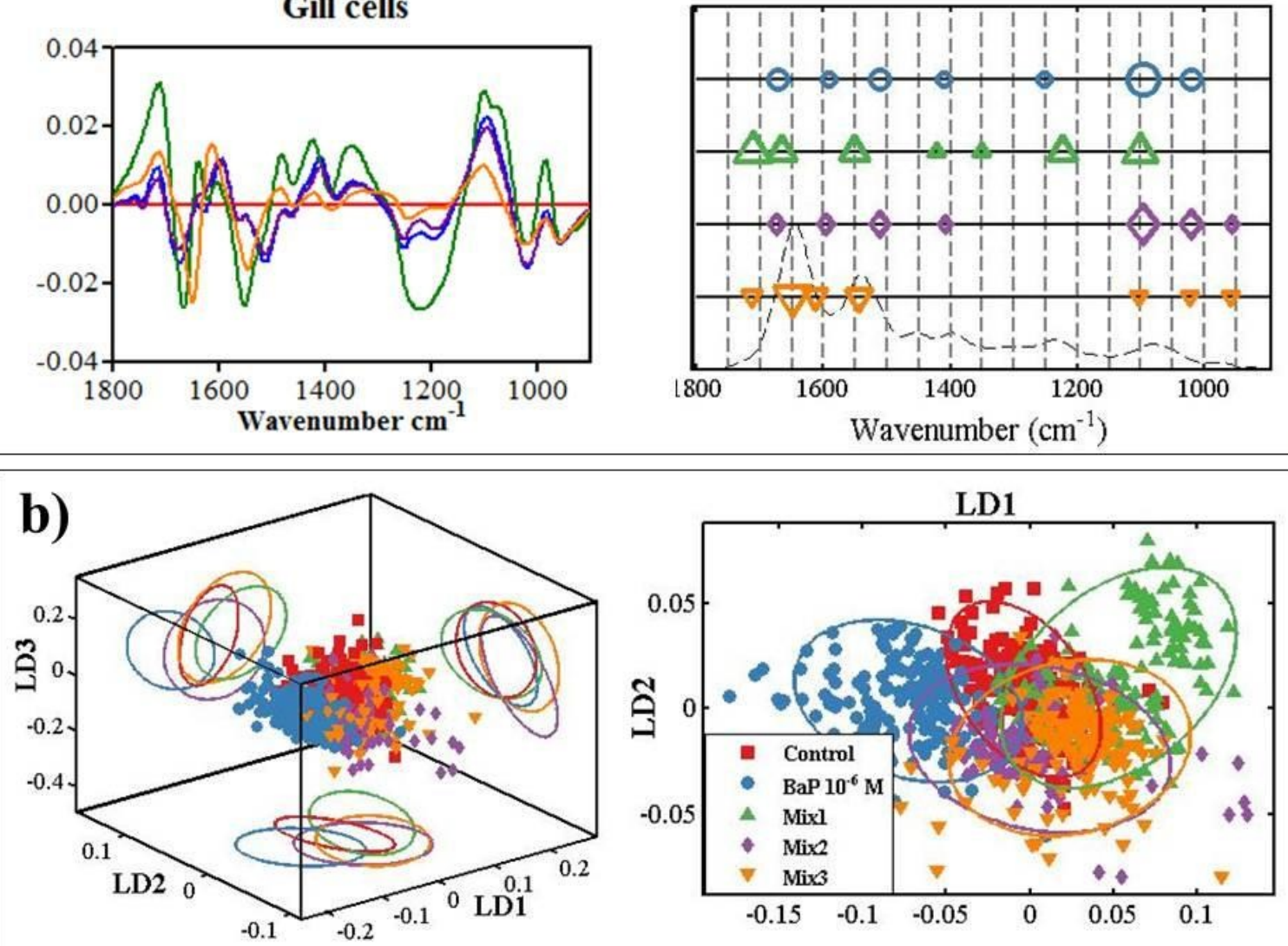

MCF-7
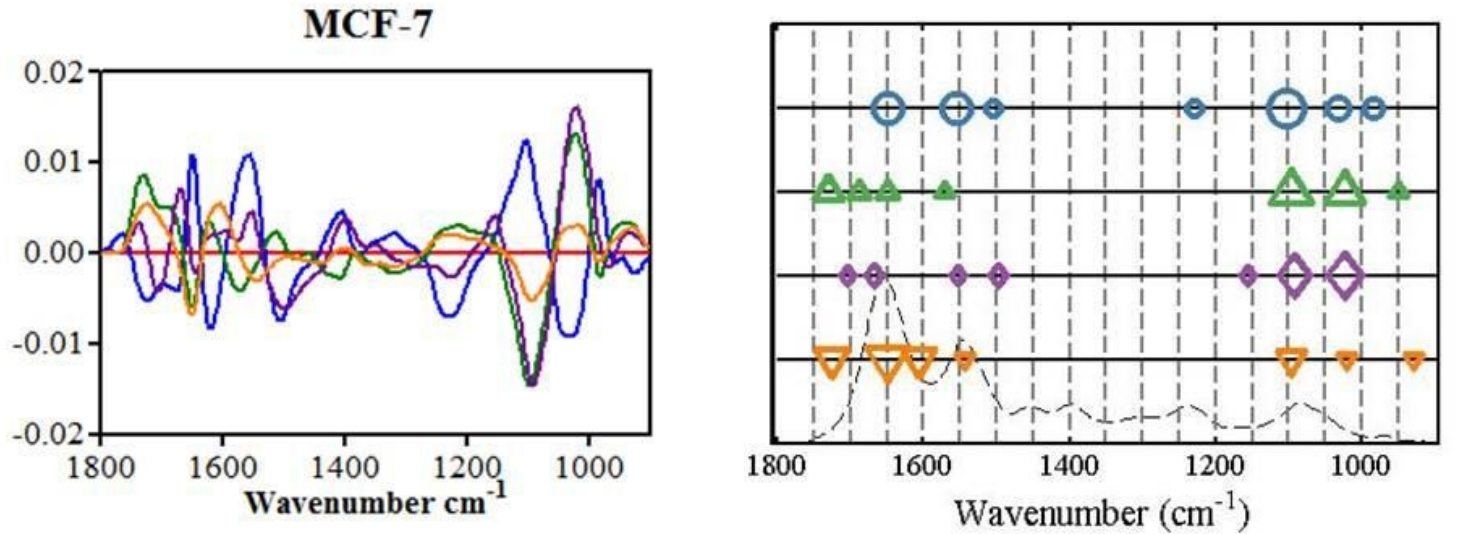

Figure 5 Scores plot and cluster vectors derived from PCA-LDA of spectral dataset (Dataset $\mathrm{B}[a] \mathrm{P}$ mix). a) Gill cells; and, $\boldsymbol{b}) \mathrm{MCF}-7$ cells. 

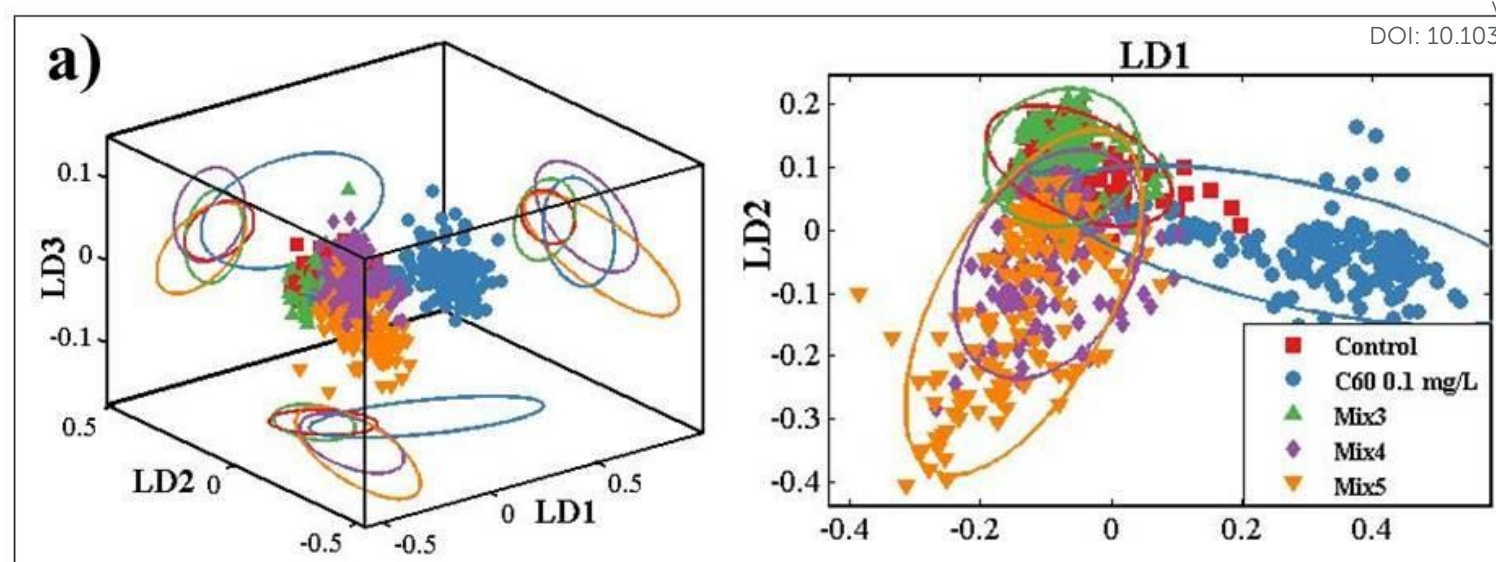

Gill cells
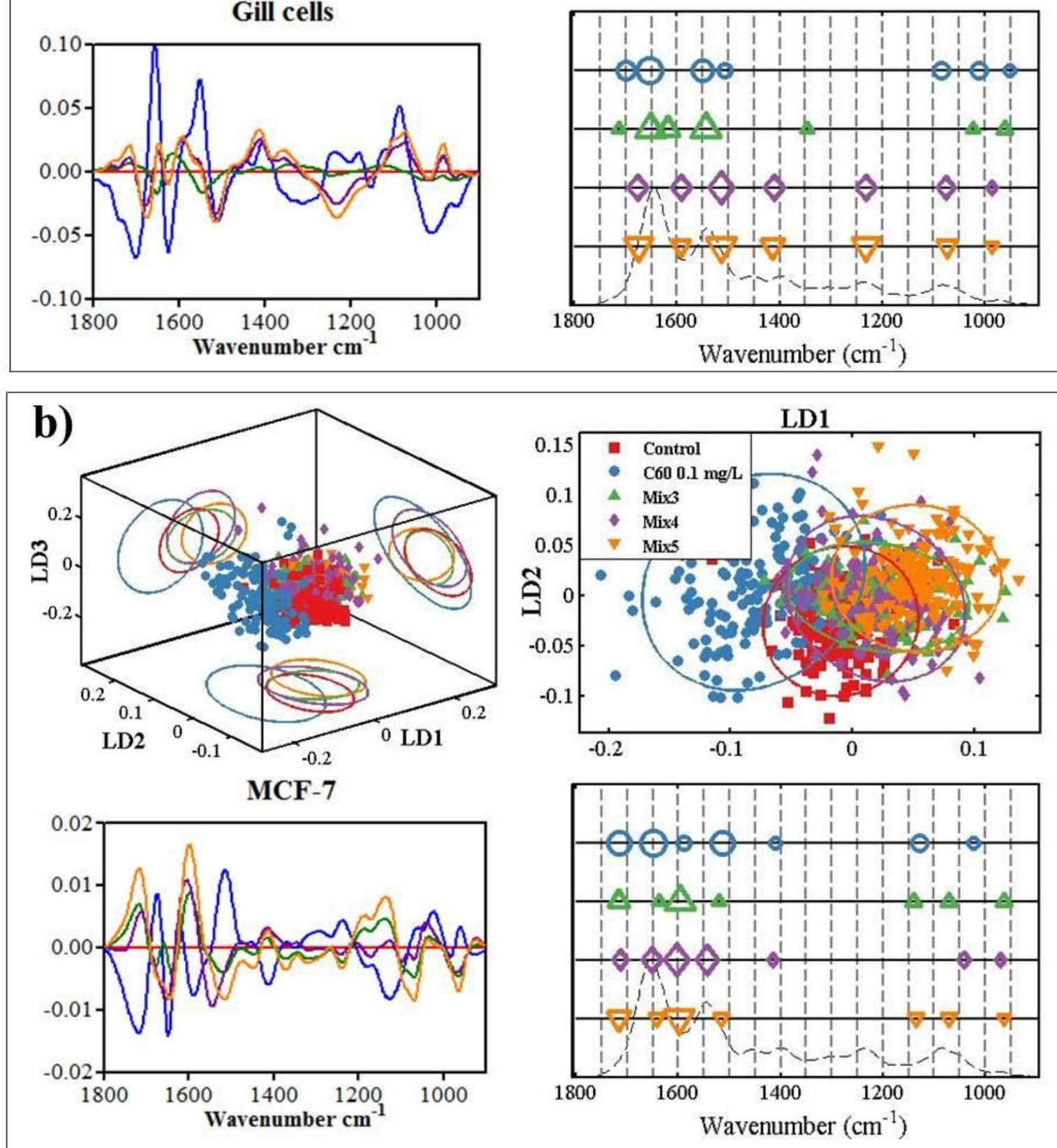

Figure 6 Scores plot and cluster vectors derived from PCA-LDA of spectral dataset (Dataset $\mathrm{C}_{60}$ mix). a) Gill cells; and, b) MCF-7 cells. 